\title{
Mid-Late Paleozoic metallogenesis and evolution of the Chinese Altai and East Junggar Orogenic Belt, NW China, Central Asia
}

\author{
Chunming HAN ${ }^{1 *}$, Wenjiao XIAO ${ }^{2,1}$, Guochun $\mathrm{ZHAO}^{3}$, Benxun $\mathrm{SU}^{1,3}$, Patrick Asamoah \\ SAKYI ${ }^{4}$, Songjian $A O^{1}$, Bo WAN ${ }^{1}$, Jien ZHANG ${ }^{1}$, Zhiyong ZHANG ${ }^{1}$, Zhongmei WANG ${ }^{1}$ \\ ${ }^{1}$ Key Laboratory of Mineral Resources, Institute of Geology and Geophysics, Chinese Academy of Sciences, Beijing 100029, China; \\ cm-han@mail.iggcas.ac.cn \\ ${ }^{2}$ Xinjiang Research Center for Mineral Resources, Xinjiang Institute of Ecology and Geography, Chinese Academy of Sciences, Urumqi \\ 830011, China \\ ${ }^{3}$ Department of Earth Sciences, The University of Hong Kong, Pokfulam Road, Hong Kong, China \\ ${ }^{4}$ Department of Earth Science, University of Ghana, P.O. Box LG 58, Legon-Accra, Ghana \\ * Corresponding author
}

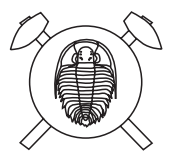

The Chinese Altai-East Junggar collage in southern Altaids is one of the largest and most important metallogenic provinces in China. It is composed of five major types of Middle to Late Paleozoic metal deposits: (1) VMS Cu-Pb-Zn, (2) porphyry $\mathrm{Cu}-\mathrm{Au}$, (3) magmatic $\mathrm{Cu}-\mathrm{Ni}$-sulfide, (4) skarn $\mathrm{Cu}-\mathrm{Mo}-\mathrm{Fe}$ and (5) orogenic $\mathrm{Au}$. Tectonically, the development of these metal deposits was closely associated with accretionary and convergent processes that occurred along the southern margin of the Central Asian Orogenic Belt (CAOB). The formation of the deposits involved three main stages, briefly described as follows: (i) Those formed during extensional back-arc volcanism along the Paleozoic active margin of the CAOB. They are Late Devonian to Early Carboniferous polymetallic volcanogenic massive sulfide deposits, together with some broadly contemporaneous $\mathrm{Fe}-\mathrm{Cu}$ skarns, located in the accreted Qiongkuer-Talate Terrane in the western Altai; (ii) Carboniferous to Permian terrane accretion and arc magmatism, resulting in widespread metalliferous ores of different types such as copper-bearing porphyries and Alaskan-type $\mathrm{Cu}-\mathrm{Ni}$-PGE zoned ultramafic bodies developed in arcs in the Buerjin-Ertai and Erqis terranes, and $\mathrm{Cu}-\mathrm{Fe}$ skarns formed in the Erqis flysch basin; (iii) Continuing accretion in the Permian leading to the development of the Dulate arc in the southern Altai associated with the formation of $\mathrm{Cu}-\mathrm{Mo}$ skarns and orogenic-type gold vein systems. The Chinese Altai-East Junggar collage typically demonstrates the various classic metalliferous ores formed during the processes of subduction-accretion and arc generation.

Keywords: Chinese Altai, East Junggar, Central Asian Orogenic Belt, Mid-Late Paleozoic, metallogenesis Received: 16 August 2013; accepted: 24 June 2014; handling editor: O. Gerel

\section{Introduction}

The Chinese Altai-East Junggar collage is one of the longest mountain chains in the Central Asian Orogenic Belt (CAOB) (Şengör et al. 1993, 1996; Buslov et al. 2001, 2004; Windley et al. 2002, 2007; Jahn et al. 2004; Safonova et al. 2011; Kruk et al. 2011) that extends NW-SE for 2,500 km from eastern Kazakhstan via northern Xinjiang in China to western Mongolia (Fig. 1). It is located between the Sayan and associated belts to the north (Federovskii et al. 1995; Xiao et al. 2004) and the Junggar Belt to the south (Zhao ZH et al. 1993; Wang JB et al. 2003). During the past fifty years many geological and ore-deposit investigations have led to the recognition of many Paleozoic orogenic gold, VMS $(\mathrm{Cu}-\mathrm{Zn}, \mathrm{Pb}-\mathrm{Zn})$, skarn $(\mathrm{Cu}-\mathrm{Mo}-\mathrm{Au}-\mathrm{Ag})$ and Alaskan-type zoned mafic-ultramafic $(\mathrm{Cu}-\mathrm{Ni}-$ PGE) mineral deposits, as well as one of the world's largest pegmatite-type rare-metal deposits (Rui et al. 2002; Goldfarb et al. 2003; Yakubchuk et al. 2003; Mao et al. 2008; Sun et al. 2008). As a result, the Altai has become a world-class metallogenic ore province (Goldfarb et al. 2003).

A better understanding of metallogenesis of these mineral deposits and their relationships with the tectonic evolution of the Chinese Altai-East Junggar collage is now possible because of several detailed studies that have been carried out in the past two decades (Wang DH et al. 2002; Wang DH 2003; Wang JB et al. 2003; Wang YW et al. 2003; Yang FQ et al. 2012, 2013). However, there have not been extensive reviews in the English language relating the tectonic evolution of the Chinese Altai-East Junggar collage to the distribution of different types of metal deposits. As a result, the international scientific community poorly understands this tectonic relationship. In this contribution, we present a detailed overview of the geological characteristics of Middle-Late Paleozoic ore deposits in the Chinese Altai-East Junggar, with emphasis on their alteration, mineralization, geochemistry, metallogenetic timing and associated lithologies, which will provide insights into the tectonic evolution of the Chinese Altai and East Junggar. 


\section{Regional geological setting}

A large number of terranes were amalgamated to the Siberian Craton since the Neoproterozoic (Şengör et al. 1993, 1996; Rui et al. 2002), and during the Paleozoic the Altai evolved by both northerly- and southerly-directed subductions (Xiao et al. 2004; Zhang ZC et al. 2005). The allochthonous terranes range from Neoproterozoic to Early Carboniferous and mainly consist of island arcs, accretionary wedges, and ophiolites accreted during long-lived Paleozoic compressional tectonics that was followed by important sinistral faulting occurring mainly at 290-280 Ma (Windley et al. 2002; Laurent-Charvet et al. 2002, 2003; Buslov et al. 2004; Xiao et al. 2004; Briggs et al. 2007). These terranes are similar to the

Tab. 1 Significant mineral occurrences in the Chinese Altai Mts.

\begin{tabular}{|c|c|c|c|c|}
\hline No. & Name & Type & Host terrane & Ore metals \\
\hline \multicolumn{5}{|c|}{ Middle to Late Devonian } \\
\hline 1 & Ashele & VMS & QA & $\mathrm{Cu}-\mathrm{Zn}$ \\
\hline 2 & Kaiyinbulake & VMS & $\mathrm{CA}$ & $\mathrm{Cu}-\mathrm{Zn}$ \\
\hline 3 & Qiaxia & VMS & QA & $\mathrm{Fe}-\mathrm{Cu}$ \\
\hline 4 & Tiemuerte & VMS & QA & $\mathrm{Cu}-\mathrm{Pb}-\mathrm{Zn}$ \\
\hline 5 & Hongdun & VMS & $\mathrm{CA}$ & $\mathrm{Pb}-\mathrm{Zn}$ \\
\hline 6 & Mengkuai & VMS & QA & $\mathrm{Cu}-\mathrm{Pb}-\mathrm{Zn}$ \\
\hline 7 & Abagong & VMS & QA & $\mathrm{Fe}-\mathrm{P}$ \\
\hline 8 & Kumasu & VMS & NA & $\mathrm{Pb}-\mathrm{Zn}$ \\
\hline 9 & Ahsemlesayi? & VMS & NA & $\mathrm{Pb}-\mathrm{Zn}$ \\
\hline 10 & Daqiao & VMS & QA & $\mathrm{Cu}-\mathrm{Pb}-\mathrm{Zn}$ \\
\hline 11 & Akeharen & VMS & QA & $\mathrm{Pb}-\mathrm{Zn}$ \\
\hline 12 & Keketale & VMS & QA & $\mathrm{Pb}-\mathrm{Zn}$ \\
\hline 15 & Shaersuoke & VMS & QA & $\mathrm{Cu}-\mathrm{Pb}-\mathrm{Zn}-\mathrm{Au}$ \\
\hline \multicolumn{5}{|c|}{ Late Carboniferous to Early Permian } \\
\hline 14 & Duolanasayi & Orogenic & QA & $\mathrm{Au}$ \\
\hline 13 & Qiaoxiahala & Skarn & $\mathrm{PE}$ & $\mathrm{Fe}-\mathrm{Cu}-\mathrm{Au}$ \\
\hline 16 & Saidu & Orogenic & QA & $\mathrm{Au}$ \\
\hline 17 & Samusongbulake & Orogenic & QA & $\mathrm{Au}$ \\
\hline 18 & Sarekuobu & Orogenic & QA & $\mathrm{Au}$ \\
\hline 19 & Hongshanzui & Orogenic & QA & $\mathrm{Au}$ \\
\hline 20 & Aketishikan & Orogenic & NA & $\mathrm{Au}$ \\
\hline 21 & Akexike & Orogenic & $\mathrm{PE}$ & $\mathrm{Au}$ \\
\hline 22 & Mengku & Skarn & QA & $\mathrm{Fe}$ \\
\hline 23 & Shaerbulake & Orogenic & PE & $\mathrm{Au}$ \\
\hline 24 & Suoerkuduke & Skarn & PE & $\mathrm{Cu}-\mathrm{Mo}$ \\
\hline 25 & Kalatongke & Magmatic & PE & $\mathrm{Cu}-\mathrm{Ni}$ \\
\hline 26 & Aketasi & Orogenic & $\mathrm{PE}$ & $\mathrm{Au}$ \\
\hline 27 & Laoshankou & Skarn & $\mathrm{PE}$ & $\mathrm{Fe}-\mathrm{Cu}-\mathrm{Au}$ \\
\hline 28 & Mareletie & Orogenic & $\mathrm{PE}$ & $\mathrm{Au}$ \\
\hline \multicolumn{5}{|c|}{ Middle Devonian to Early Carboniferous } \\
\hline 29 & Xileketashihalasu & Porphyry & $\mathrm{PE}$ & $\mathrm{Cu}-\mathrm{Au}$ \\
\hline 30 & Yulekenhalasu & Porphyry & PE & $\mathrm{Cu}$ \\
\hline 31 & Xietekehalasu & Porphyry & PE & $\mathrm{Cu}$ \\
\hline 32 & Tuosibasitao & Porphyry & QA & $\mathrm{Cu}-\mathrm{Fe}$ \\
\hline 33 & Kalasayi & Porphyry & QA & $\mathrm{Cu}$ \\
\hline
\end{tabular}

Abbreviations for host terranes (Fig. 1a): $\mathrm{HS}=$ Hanasi; $\mathrm{NT}=$ Nuoerte; $\mathrm{CA}=$ Central Altai; QA = Qiongluer-Abagong; EQ = Erqis; $\mathrm{PE}=$ Puerkin-Ertai super-terranes in the Cordilleran Orogen of NW America (Şengör et al. 1996; Goldfarb et al. 2003). On the basis of stratigraphy, metamorphism, mineralization, deformation patterns and age relations, six distinct terranes have been recognized in the Chinese Altai-East Junggar (Windley et al. 2002) (Fig. 1; Tab. 1).

The Hanasi Terrane (also called "Kanasi") (Fig. 1a) in northernmost Xinjiang consists of the Neoproterozoic to Mid-Ordovician fossiliferous Habahe Grp. and Late Ordovician Baihaba Fm. that were metamorphosed at sub-greenschist facies conditions (Windley et al. 2002). The Habahe Grp. comprises sandstone, siltstone, shale, marble and chert, while the Baihaba Fm. consists of shale, limestone, tuff, granite-porphyry, chert, andesite, andesitic agglomerate and andesitic breccia. The Baihaba

Fm. is considered to have had a source in a continental-margin andesitic volcanic arc, having been deposited in a fore-arc environment (Windley et al. 2002; Goldfarb et al. 2003). The plutons in the Hanasi Terrane are mainly biotite and two-mica granites that are undated, except for the Hanas Lake and Halong-Balisi granites that yielded whole-rock $\mathrm{Rb}-\mathrm{Sr}$ isochron ages of $346 \pm 5$ to $404 \pm 3 \mathrm{Ma}$ (Liu W 1993) and the Hanasi granite with a whole-rock $\mathrm{Sm}-\mathrm{Nd}$ isochron age of $390 \pm 2 \mathrm{Ma}$ (Zhao ZH et al. 1993).

The Nuoerte Terrane in northeastern Altai contains the Upper Devonian Mangdaiqia Fm. comprising intermediate volcanic rocks, shale, siltstone, greywacke and limestone, and the Lower Carboniferous Hongshanzui Fm. that consists of sandstone, slate, limestone and intermediate-felsic volcanic rocks (Zhou et al. 2000; Windley et al. 2002). Windley et al. (2002) pointed out that this terrane may represent two Mid-Late Devonian to Early Carboniferous accreted oceanic arcs which were the same as those in the Delyun-Saksai sub-unit of the Kanarhirin-Western Sayan accretionary wedge and arc of Şengör et al. (1993).

The Central Altai Terrane is made up of abundant granites and some Mid-Ordovician to Silurian metasediments (Long et al. 2008). Two idiomorphic zircons from a rhyodacite recorded a mean zircon evaporation $\mathrm{Pb}-\mathrm{Pb}$ age of $505 \pm 2 \mathrm{Ma}$ that reflects the time of felsic arc volcanism, while the presence of 920-614 Ma xenocrysts that survived intracrustal melting suggests the development of a continental magmatic arc on the southern margin of a Precambrian micro-continent (Windley et al. 2002). Four zircons from an orthogneiss gave a zircon evaporation $\mathrm{Pb}-\mathrm{Pb}$ protolith age of $415 \pm 1 \mathrm{Ma}$ (Windley et al. 2002). Metasediments in two 


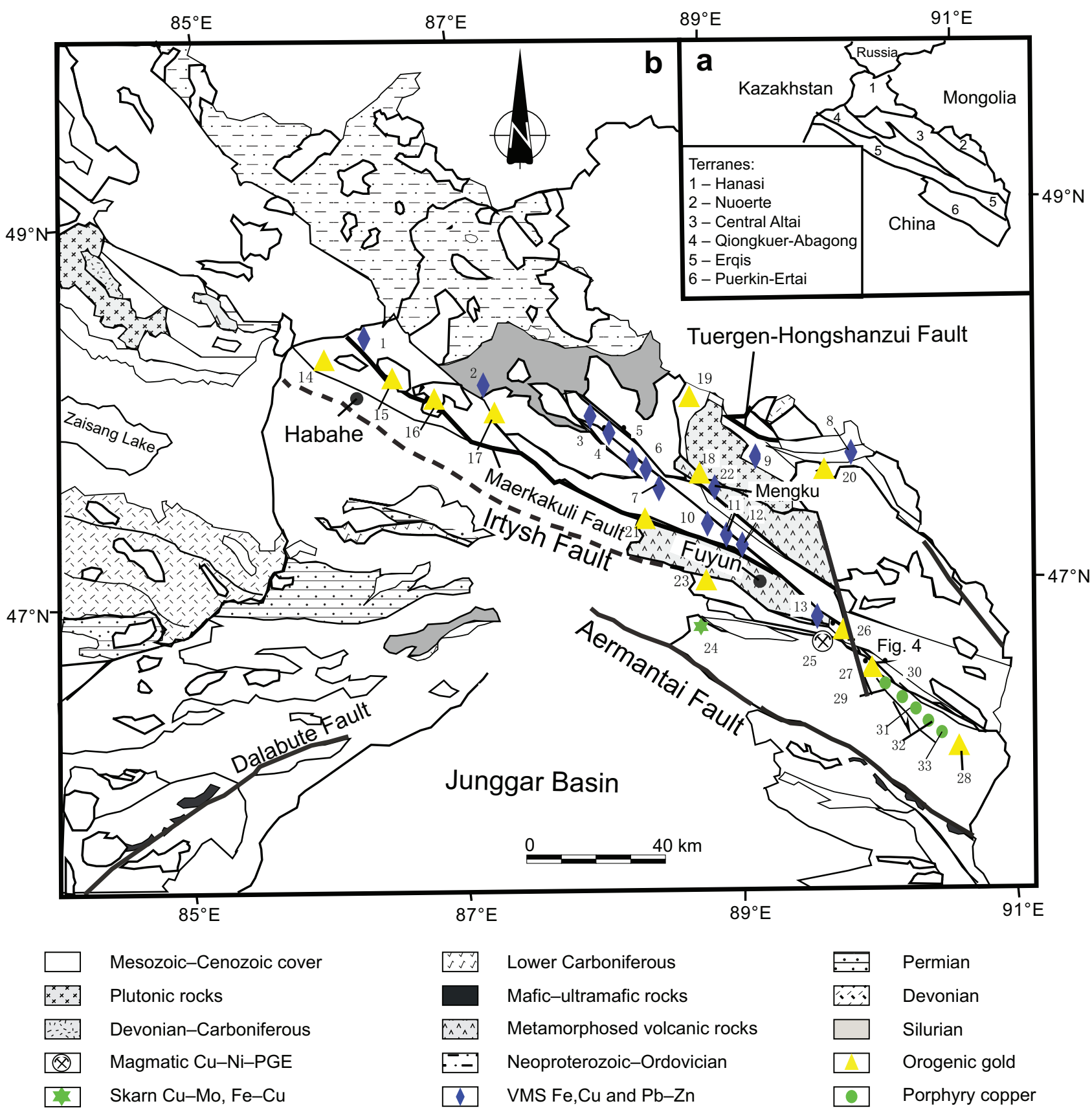

Fig. 1 Generalized geological map of the Altai Shan, NW China, showing the locations of important mines. The insert, after Windley et al. (2002), shows the distribution of the terranes. Key to mines: $V M S C u-P b-Z n: 1=$ Ashele, $2=$ Kaiyinbulake, $3=$ Qiaxia, $4=$ Tiemuerte, $5=$ Hongdun, $6=$ Mengkuai, 7 = Talate, $8=$ Kumasu, $9=$ Ahsemlesayi, $10=$ Daqiao, $11=$ Akeharen, $12=$ Keketale, $13=$ Sharesuoke, $22=$ Mengku; Orogenic gold: 14 = Duolanasayi, $15=$ Qiaoxiahala, $16=$ Saidu, $17=$ Samusuongbulake, $18=$ Sarekuobu, $19=$ Hongshanzui, $20=$ Aketishikan, $21=$ Akexike, 23 = Shaerbulake, $26=$ Aketasi, $27=$ Laoshankou, $28=$ Mareletie; Porphyry copper: $29=$ Xileketashihalasu, $30=$ Yulekenhalasu, $31=$ Xietekehalasu, 32 = Tuosibasitao, 33 = Kalsayi; Skarn Cu-Mo: 24 = Suoerkuduke; Magmatic Cu-Ni: 25 = Kalatongke.

locations in this terrane yielded $\mathrm{U}-\mathrm{Th}-$ total $\mathrm{Pb}$ isochron ages (CHIME) on monazite of $381 \pm 45 \mathrm{Ma}, 381 \pm 36$ $\mathrm{Ma}$ and $261 \pm 12 \mathrm{Ma}$, timing the regional metamorphism (Zheng et al. 2007). In the eastern part of the terrane, major garnet-bearing, post-tectonic anatectic granites are bordered by abundant pegmatites enriched in muscovite, spodumene, beryl and REE deposits (Fig. 1).
The Qiongkuer-Abagong Terrane contains the Upper Silurian Kumuti Fm. composed of greenschist- to amphibolite-facies schists, the Lower Devonian Kangbutiebao Fm. composed mainly of oceanic arc-type volcanic and pyroclastic rocks, the Lower to Mid-Devonian Ashele Fm. that contains fossiliferous sediments, basaltic pillow lavas, hyaloclastites, massive basaltic lavas, lapilli tuffs 
and dacitic lavas (Niu et al. 2006; Yang FQ et al. 2014), and the Mid-Devonian Altai Fm. of low-grade forearc turbidites. The presence of high-Mg andesites and high-Mg adakites in the Ashele Fm. indicates that they formed in a forearc setting (Niu et al. 1999; Zhang ZC et al. 2005; Wan et al. 2010). Metasediments from four locations in the Qiongkuer-Abagong Terrane gave U-Thtotal $\mathrm{Pb}$ isochron ages (CHIME) on monazite of $377 \pm 30$ $\mathrm{Ma}$ and $268 \pm 10$ to $261 \pm 20 \mathrm{Ma}$, reflecting the times of regional metamorphism (Zheng et al. 2007). Close to the latter interval are the following ages: $\mathrm{a} \mathrm{Rb}-\mathrm{Sr}$ wholerock age of metavolcanic rocks $(285 \pm 2 \mathrm{Ma}$ : Windley et al. 2002 and references therein), a SHRIMP U-Pb zircon age for orthogneiss (281 $\pm 3 \mathrm{Ma}$ : Hu et al. 2006), a Rb-Sr whole-rock age of a granite pluton $(256 \pm 5 \mathrm{Ma}$ : Liu W 1993) and a SHRIMP U-Pb zircon age of a posttectonic Lamazhou granitic pluton (276 \pm 9 Ma: Wang T et al. 2005).

The Qiongkuer-Abagong Terrane is dominated by a Devonian group, which developed along the edge of the Paleo-Asian Ocean and extends into the southern Urals (Şengör et al. 1993; Dobretsov et al. 1995; Şengör et al. 1996; Buslov et al. 2001; Yakubchuk et al. 2003; Safonova et al. 2011). The terrane contains many major ore deposits including orogenic-type gold, rare metal pegmatites, skarns and VMS deposits (Goldfarb et al. 2003; Yakubchuk et al. 2003). The VMS $\mathrm{Cu}-\mathrm{Zn}$ and $\mathrm{Pb}-\mathrm{Zn}$ deposits (e.g. Ashele and Keketale) formed in the forearc setting (Wan et al. 2010), whereas the orogenic gold deposits (e.g., Saidu and Duodalasayi) developed in association with collision tectonics (Yakubchuk et al. 2003). This terrane is probably equivalent to the Rudnyi Altai Block in Russian Altai (Buslov et al. 2001, 2004; D'yachkov et al. 2009; Kruk et al. 2011), and the Turgen Block in eastern Mongolia (Badarch et al. 2002; Goldfarb et al. 2003).

The Erqis (Irtys, Irtysh) Terrane is situated between Terrane 4 and the Erqis Fault. The terrane contains Mid-Ordovician to Silurian schists unconformably overlain by the Upper Carboniferous Kalaerqis Fm., which is also tectonically overlain by the Lower Permian Tesibaerhan Fm. and intruded by Permian granites (Qu and Zhang 1991; Windley et al. 2002; Long et al. 2008). There are different types of mélanges in this terrane. In the Suoerkuduke area (no. 24 on Fig. 1b), a mélange contains blocks of adakite, basalt, andesite, diorite, dolerite, lithic tuff, and limestone with Devonian crinoids. According to Niu et al. (2006), the adakite was generated by melting of subducted oceanic crust. In the Shaerbulake area (no. 23 on Fig. 1b), another tectonic mélange contains blocks of basalt, andesite, volcanic tuff, dolerite-gabbro, and two types of boninitic rocks, a massive lava and a pillow lava or breccia. The geochemical features of the boninites suggest that they were formed by melting of mildly refractory mantle peridotites fluxed by a slab-derived fluid component (Niu et al. 2006). From the juxtaposition of Devonian volcanic rocks of different origins such as boninites, adakites, high- and low- $\mathrm{TiO}_{2}$ basalts within limited area, Niu et al. (2006) concluded that complex accretion and tectonic processes including duplex thrusting, strike-slip faulting and serpentinite diapirism were active during DevonianCarboniferous convergence and subduction-accretion. The Erqis Fault is the most prominent terrane-bounding fault in the Altai, extending for more than $1000 \mathrm{~km}$ into adjacent Kazakhstan and Mongolia (Buslov et al. 2001, 2004; D'yachkov et al. 2009; Kruk et al. 2011). It is defined by zone of mylonites a $5-10 \mathrm{~km}$ wide dated by ${ }^{40} \mathrm{Ar}-{ }^{39} \mathrm{Ar}$ method on biotite at $290 \pm 2$ to $281.4 \pm 8.0 \mathrm{Ma}$ (Travin et al. 2001; Laurent-Charvet et al. 2002). The Erqis Terrane is interpreted to have collided with, and was accreted below, the southern boundary of Terrane 4, during which the Erqis Fault underwent at least 1000 $\mathrm{km}$ sinistral strike-slip movement.

The Puerkin-Ertai Terrane is situated between the Irtysh and Aermantai faults. It consists of a Devonian island arc that contains felsic to intermediate basic lavas and tuffs, andesitic and dacitic porphyries, and contemporaneous calc-alkaline granitic plutons, together with shales, sandstones, conglomerates and limestones (Mei et al. 1993; Yu et al. 1993; Windley et al. 2002).

The Devonian volcanic rocks enclose many small blocks of Upper Ordovician limestone. A small early Carboniferous island arc in the Puerkin-Ertai Terrane was intruded by several Permian granitic plutons that are associated with the Suoerkudouke $\mathrm{Mo}-\mathrm{Cu}-\mathrm{Au}-\mathrm{Ag}$ and Qiaoxiahala $\mathrm{Fe}-\mathrm{Cu}-\mathrm{Au}$ deposits (Han $\mathrm{BF}$ et al. 1997) and mafic-ultramafic complexes, one of which hosts the Kalatongke $\mathrm{Cu}-\mathrm{Ni}-\mathrm{PGE}$ deposit (Wang $\mathrm{RM}$ et al. 1991). Yang WP et al. (2005) recognized the Xileketehalasu porphyry $\mathrm{Cu}-\mathrm{Au}$ deposit in a Devonian island arc, for which reason the terrane has become an important base and a precious metal target area in Xinjiang.

\section{Mineral deposit types and their major characteristics}

The Chinese Altai-East Junggar is remarkable for the diversity of its mineralization. There are more than 220 mines and prospects in an area of $c .110,000 \mathrm{~km}^{2}$ (Wang DH et al. 2002). Five types of deposits are distinguished on the basis of their morphology, host rocks, structural setting, and mineral assemblages (Goldfrab et al. 2003); their characteristics are summarized in Tab. 2 while the spatial distribution is shown in Fig. 1b. 

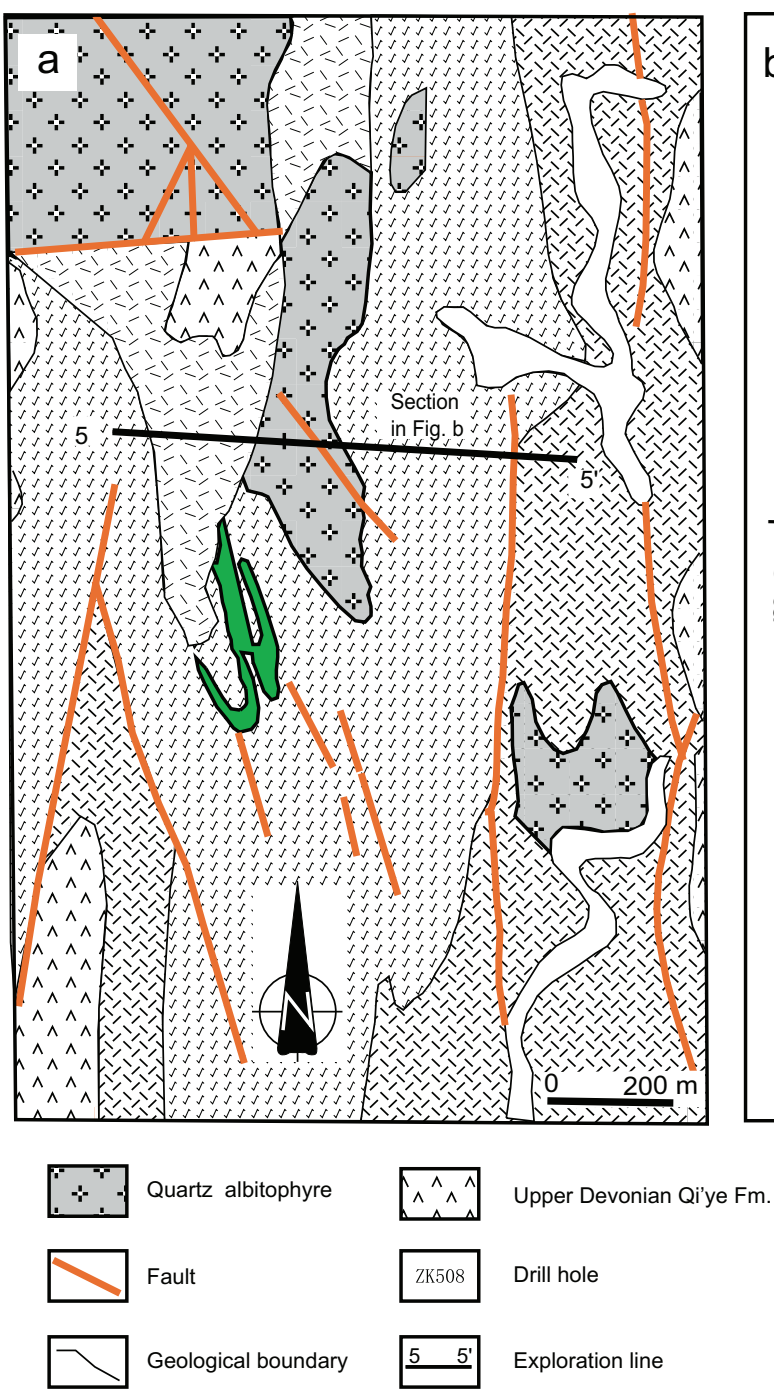

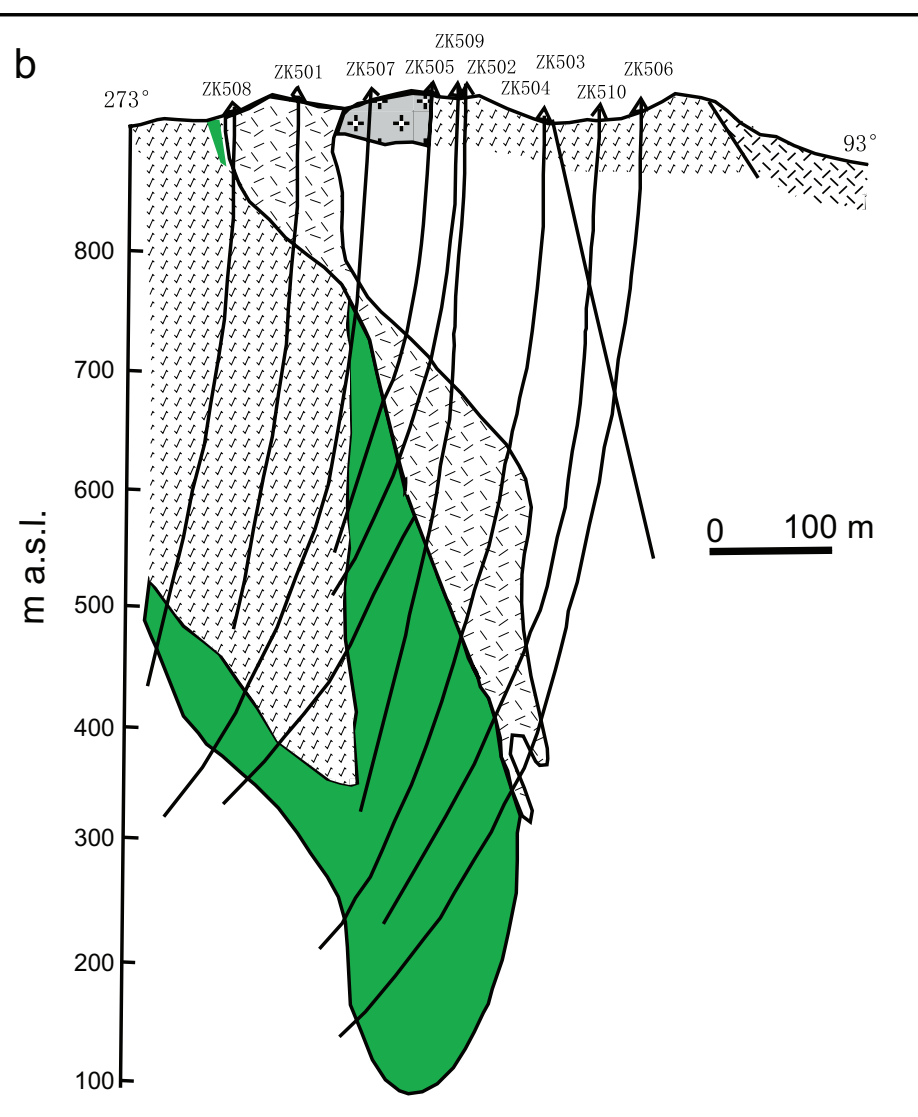

Mid-Devonian Ashele Fm.

突空企 The first member

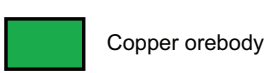

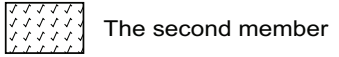

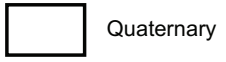

E⿺辶寸系 The third member

Fig. 2 Geological map of the Ashele Cu-Zn district (after Wang DH 2003). For location see No. 1 in Fig. 1.

\subsection{Mid-Devonian VMS Cu-Pb-Zn deposits}

In the Qiongkuer-Talate Terrane (Fig. 1) there are more than ten VMS $\mathrm{Cu}-\mathrm{Pb}-\mathrm{Zn}$ deposits at Ashele, Keketale, Daqiao, Talate, Tiemuerte, Akeharen and Qiaxia (Wang $\mathrm{DH}$ et al. 2002). These deposits are restricted to a NWtrending corridor of VMS $\mathrm{Cu}-\mathrm{Pb}-\mathrm{Zn}$ deposits over 360 $\mathrm{km}$ long and 30-70 km wide (Goldfarb et al. 2003); Ashele and Keketale represent large-scale ore deposits (Wang DH et al. 2002; Han CM et al. 2006).

\subsubsection{Ashele $\mathrm{Cu}-\mathrm{Zn}$ deposit}

The Ashele $\mathrm{Cu}-\mathrm{Zn}$ deposit is located $30 \mathrm{~km} \mathrm{NW}$ of Habahe city. It was discovered during a regional geological survey in 1984 and mining production began in 2004. It is estimated to contain a reserve of $1.08 \mathrm{Mt} \mathrm{Cu}, 0.43 \mathrm{Mt} \mathrm{Zn}$, $10 \mathrm{t} \mathrm{Au}$, and $860 \mathrm{t} \mathrm{Ag}$, with ore grades averaging $3.42 \%$
$\mathrm{Cu}, 6.65 \% \mathrm{Zn}, 0.6 \mathrm{~g} / \mathrm{t} \mathrm{Au}$ and 20-60 g/t Ag (Wang JB et al. 1998; Wang DH 2003).

The main stratigraphic units exposed in the ore district are the Lower-Middle Devonian Ashele Fm. and Upper Devonian Qiye Fm. The ore bodies are mainly hosted by tuffs and breccias associated with basalt and quartz keratophyre in the hanging wall of a volcanic arc in the Qiye Fm. The principal structures of the ore district are $\mathrm{N}-\mathrm{S}$-trending folds and faults that mostly post-date the ores. Generally, volcanic edifices formed at the intersections of two faults. Seven mineralization zones are distributed along $\mathrm{N}$-S-trending faults; the length of each zone ranges from several meters to a maximum of $1 \mathrm{~km}$, and the average width is up to tens of meters. Ore body No. 1, the largest in the district, is a lens-shaped mound, concordant with the folded bedding, accompanied by a number of small vein-type ore bodies. The main ore body strikes $\mathrm{N}-\mathrm{S}$, dipping at $50^{\circ} \mathrm{E}$ (Fig. 2). 


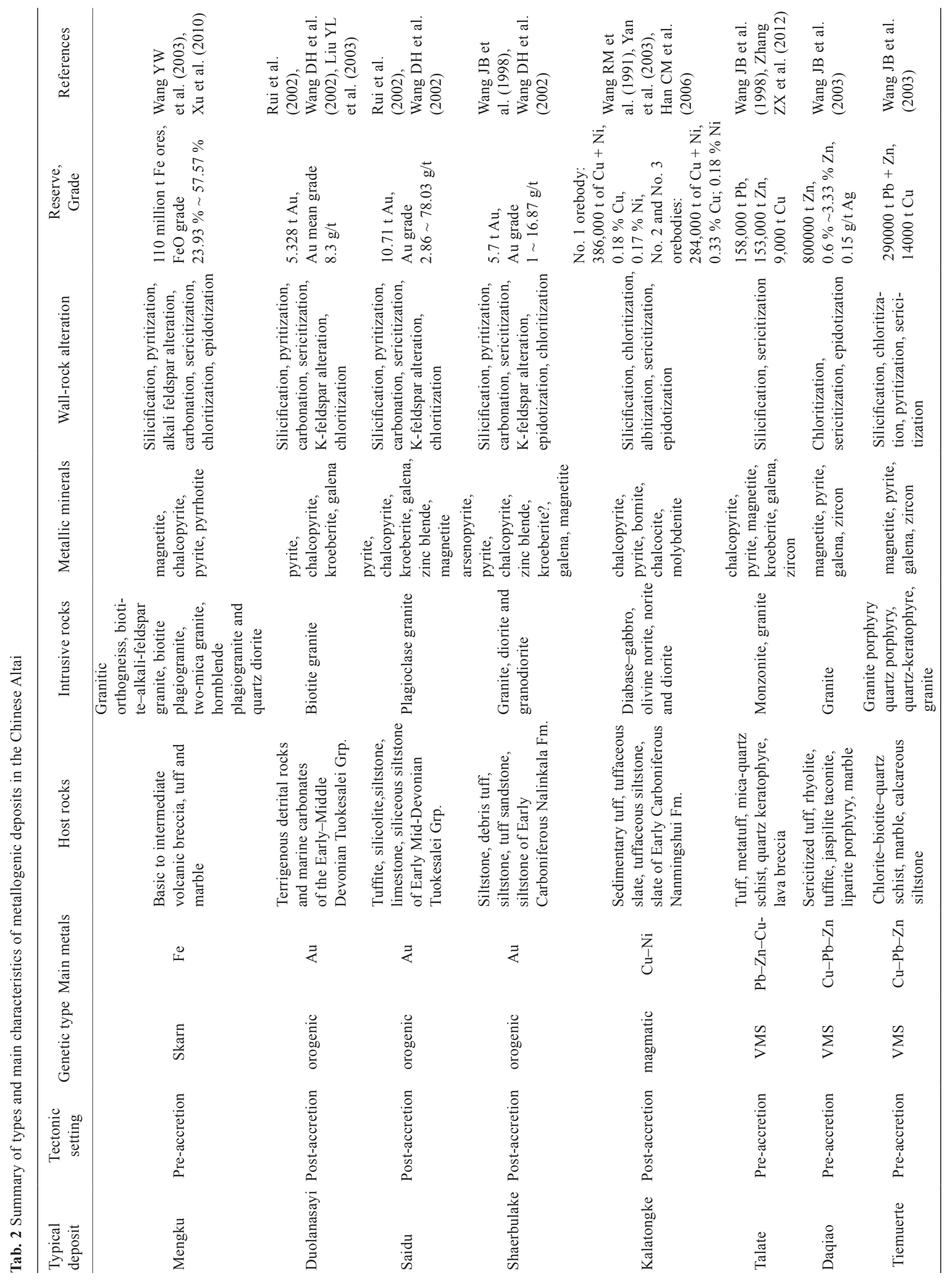




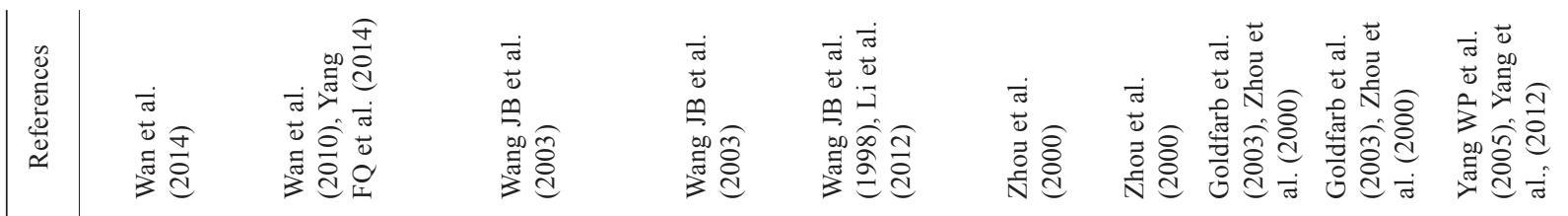

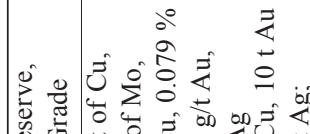

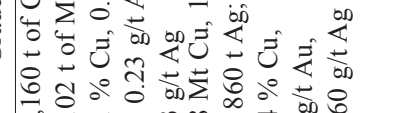

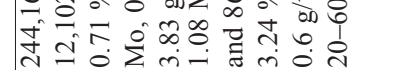

잉 $\quad \therefore$

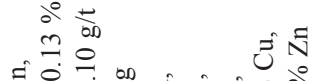

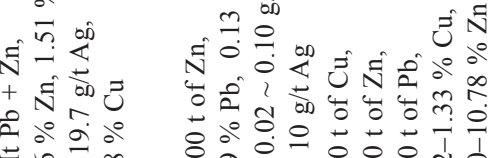

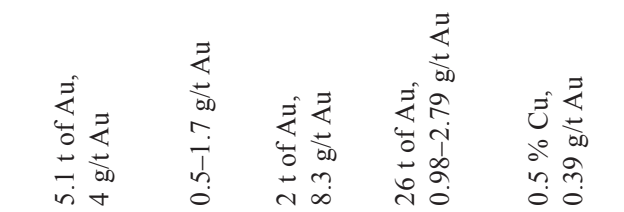

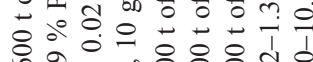

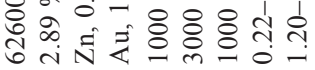

势

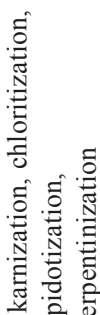

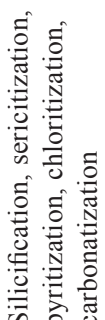

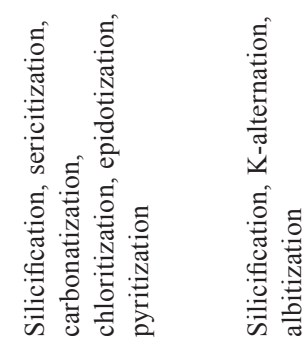

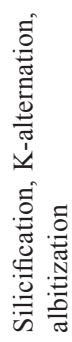

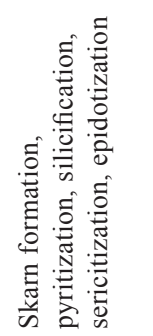

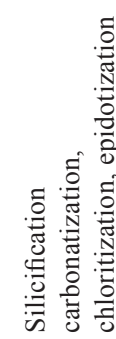

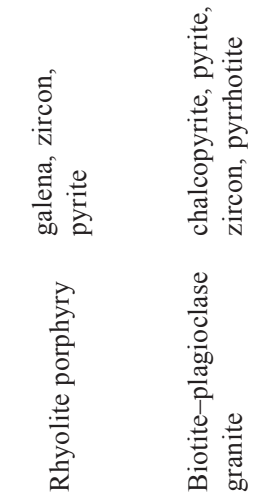

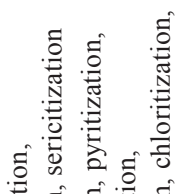

莺

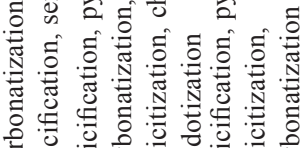

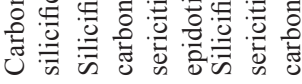

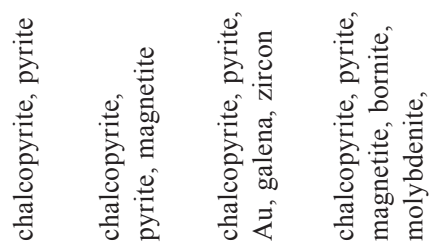

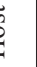

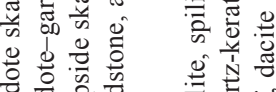

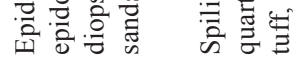

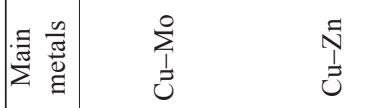

$\sum_{>}^{\infty}$

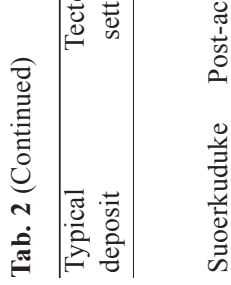

贾。

竞

莺通

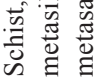

సี

क

$\sum_{>}^{\infty}$

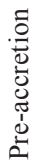

$\frac{0}{\frac{0}{2}}$

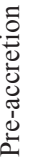

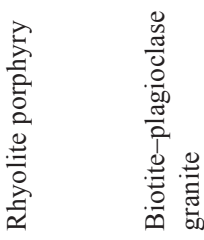

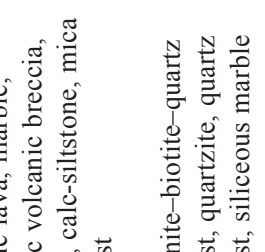

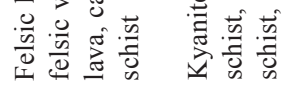

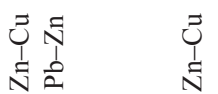

$\sum_{i}^{\infty} \quad \sum_{>}^{\infty}$

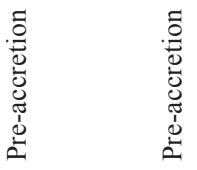

象舵

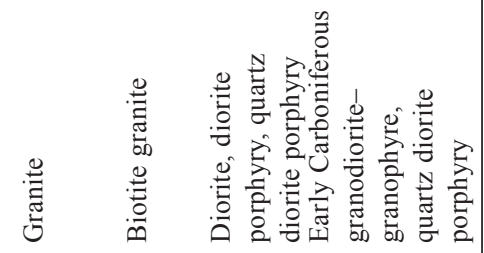

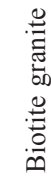

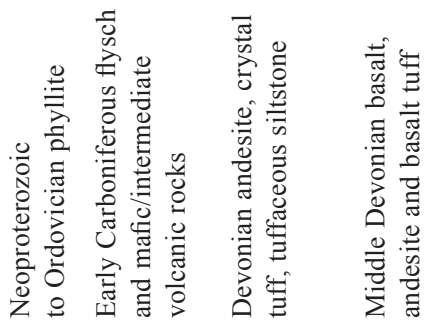

z $z$ द

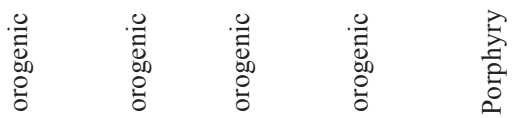

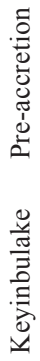

.

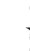

樆

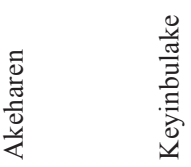

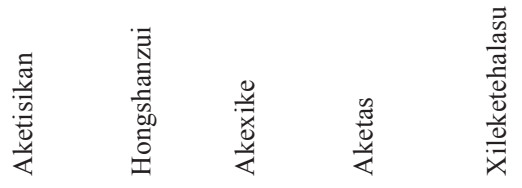

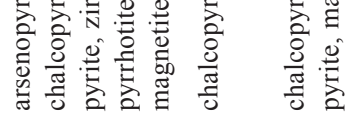


The ores exhibit massive, densely disseminated, banded, veinlet-disseminated, and brecciated structures. The orebody has pronounced vertical zoning, with its lower part consisting of veined and veinlet-disseminated ores and the middle and upper parts made up of massive ores. From the center of the ore body towards its margins, the ore types include massive, through banded to disseminated. The dominant ore is $\mathrm{Cu}$, and associated metals include $\mathrm{Zn}, \mathrm{Ag}, \mathrm{Pb}, \mathrm{S}$ and $\mathrm{Ba}$, with minor $\mathrm{Au}, \mathrm{Se}$, $\mathrm{Cd}, \mathrm{Te}$ and $\mathrm{Ga}$.

The ore minerals are dominantly pyrite and chalcopyrite and subordinate sphalerite, galena, tennantite, argentite, bornite and cubanite. Based on crosscutting relationships, Chen et al. (1996) defined seven stages of mineralization. Stage 1 is characterized by pyritization, with a representative ore mineral assemblage of quartz + pyrite, which is euhedral-granular and subhedral-granular. Stage 2 is characterized mainly by a quartz + pyrite + chalcopyrite assemblage that is anhedral-granular. Stage 3 is represented by a quartz + sphalerite + pyrite + chalcopyrite assemblage, while stage 4 is marked by quartz + sphalerite + pyrite + chalcopyrite + galena + tetrahedrite. Stage 5 consists of pyrite + barite, and stage 6 is represented by quartz + pyrite + chalcopyrite + calcite assemblage that occurs in veins. Stage 7 is marked by supergene oxidation that gave rise to secondary minerals such as malachite + limonite + jarosite + covellite.

The homogenization temperature of fluid inclusions varies between 168 and $319^{\circ} \mathrm{C}$ and the salinity of fluid inclusions is $1.2-12.4$ wt. $\% \mathrm{NaCl}$ equ. The $\delta \mathrm{D}(-142.3$ to $-39 \%$ ) and $\delta^{18} \mathrm{O}(-12.3$ to $-0.3 \%$ ) values of mineralizing fluids indicate a meteoric origin (Wang DH et al. 2002).

\subsubsection{Keketale Pb-Zn deposit}

The Keketale $\mathrm{Pb}-\mathrm{Zn}$ deposit was discovered in 1986 and is located $\sim 95 \mathrm{~km}$ southeast of Altai city (Fig. 1b). It has reserves of $3 \mathrm{Mt} \mathrm{Pb}+\mathrm{Zn}$ and $650 \mathrm{t} \mathrm{Ag}$, with ore grades averaging $3.16 \% \mathrm{Zn}, 1.51 \% \mathrm{~Pb}$, and $19.7 \mathrm{~g} / \mathrm{t} \mathrm{Ag}$ (Wang JB et al. 1998). In the ore district the dominant Lower Devonian Kangbutiebao Fm. can be further divided into lower and upper successions. The lower one consists of intermediate-felsic lavas, pyroclastic rocks and terrigenous clastic rocks, and the upper one comprises maficfelsic volcanic rocks, terrigenous clastic sediments and carbonates. The deposit is located in the upper succession of the Kangbutiebao Fm.

Many faults in the mineralized area trend predominantly WNW-ESE. The major structure in the area is the Maizi overturned syncline. Magmatic rocks include mainly Devonian granites and minor intermediate-basic dikes and stocks near the fault zone, as well as quartz(albite) porphyry dikes (Fig. 3).

At the Keketale deposit, a total of 15 ore bodies striking $130-170^{\circ}$ and dipping NE at $47-85^{\circ}$ have been identified. The gangue minerals present are quartz, plagioclase, muscovite, calcite, diopside, tremolite, almandine, biotite, hornblende and epidote. The ores have finely granular, corroded and interstitial textures, and are disseminated,

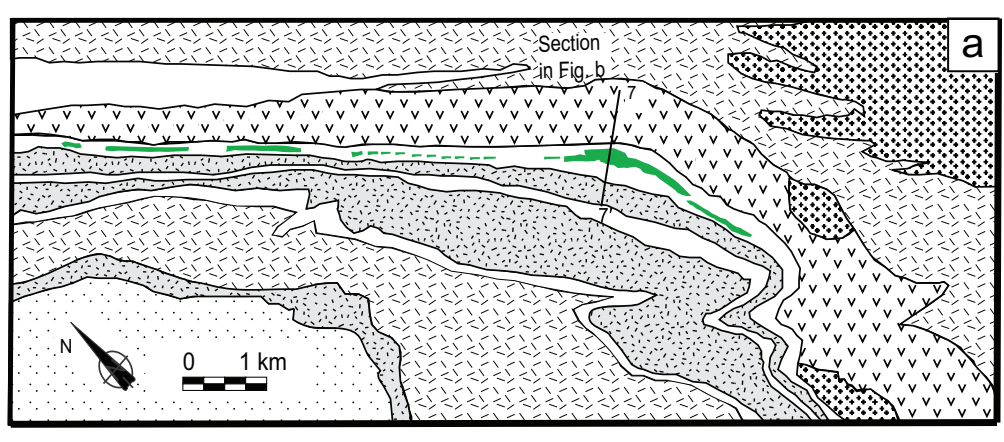

Middle Devonian sedimentary rocks

Lower Devonian fragment-bearing tuff

$\Delta \Delta_{\Delta \Delta \Delta}^{\Delta \Delta}$ Lower Devonian tuff agglomerate

Devonian granite porphyry

$\mathrm{Pb}-\mathrm{Zn}$ ore body
Middle Devonian sedimentary rocks

Lower Devonian tuff

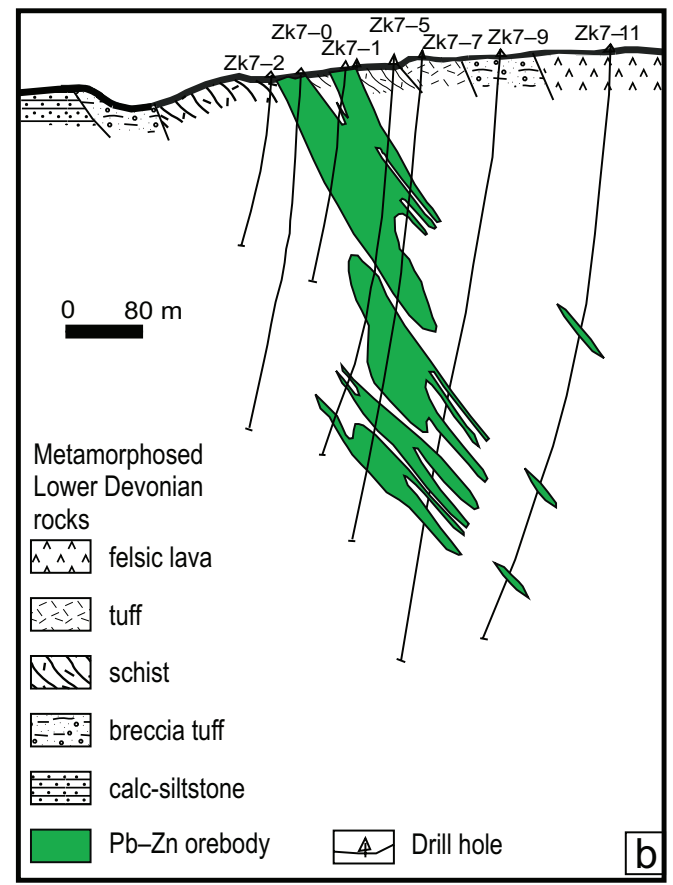

Fig. 3 Geological map of the Keketale $\mathrm{Pb}-\mathrm{Zn}$ deposit (after Wang JB et al. 2003). The $\mathrm{Pb}-\mathrm{Zn}$ ore bodies are hosted in a metasediment in the Lower Devonian volcano-sedimentary succession of the Upper Kangbutiebao Fm. For location see No. 12 in Fig. 1. 
massive, with less common banded, laminated, stockwork and brecciated structures. Lead grade in the ore bodies ranges from 0.38 to $4.95 \%$, with a mean of $1.51 \%$; $\mathrm{Zn}$ grade varies from 0.40 to $10.74 \%$, with an average of $3.16 \%$, while the mean grade of $\mathrm{Pb}+\mathrm{Zn}$ is $4.67 \%$. The $\mathrm{Ag}$ grade is commonly less than $40 \mathrm{~g} / \mathrm{t}$, but reaching $222 \mathrm{~g} / \mathrm{t}$. Based on the mineral assemblages, Wang JB et al. (1998) divided the mineralization into two stages: an early pyrrhotite + pyrite + sphalerite + galena mineralization and late-stage pyrite + galena veins.

\subsection{Middle Devonian-Early Carboniferous porphyry Cu deposits}

Middle Devonian-Early Carboniferous subduction-related tectonics in the Puerkin-Ertai Terrane, immediately prior to its final docking along the southern margin of Erqis Fault zone, were coincident with a major phase of porphyry formation. Alkaline plutons within Middle Devonian tuffs and andesite are associated with porphyry $\mathrm{Cu}-\mathrm{Au}$ deposits at Xileketekalasu, Yulekenhalasu, Xietekehalasu, Tuosibasitao and Kalasayi (Fig. 1).

The Xileketekalasu deposit has been best studied and is widely considered to be one of the most economically significant deposits in the Altai Mts. It has reserves of about $227685 \mathrm{t}$ of $\mathrm{Cu}$ and $7 \mathrm{t}$ of $\mathrm{Au}$ based on average ore grades of $0.50 \% \mathrm{Cu}$ and $0.39 \mathrm{~g} / \mathrm{t} \mathrm{Au}$ (Yang WP et al. 2005; Fig. 4). The principal ore minerals are chalcopyrite

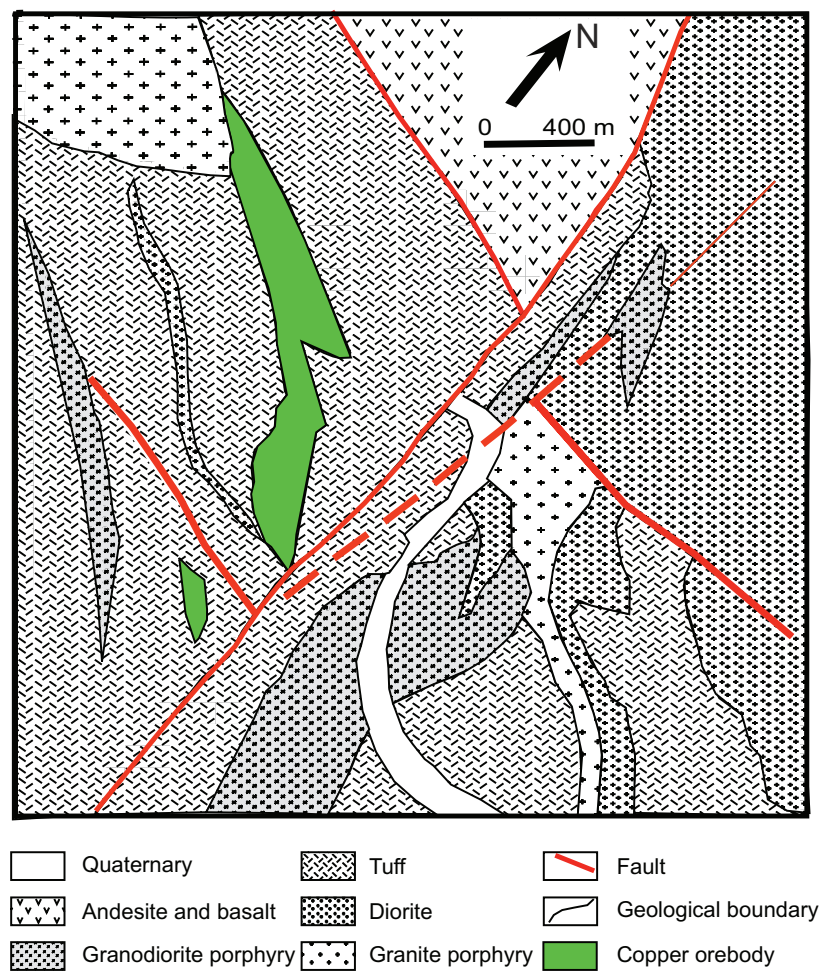

Fig. 4 Geological map of the Xilekelekalasu $\mathrm{Cu}-\mathrm{Au}$ district (after Yang WP et al. 2005). For location see No. 31 in Fig. 1. and pyrite; the minor ones are bornite, molybdenite and magnetite. Gangue minerals are mainly quartz, plagioclase, sericite, chlorite, epidote and calcite. The ore has a medium- to fine-grained, subhedral to anhedral granular texture, and disseminated and veinlet- disseminated structures. Yang WP et al. (2005) recognized three alteration zones: potassic, phyllic and propylitic. The mineralized porphyries have chemical affinities to adakites, which suggests that their origin was related to partial melting of oceanic crust due to northward-dipping subduction of the Junggar Ocean in the Devonian to Early Carboniferous times.

\subsubsection{Late Carboniferous-Early Permian magmatic $\mathrm{Cu}-\mathrm{Ni}$ deposits}

The Kalatongke mafic-ultramafic intrusion hosts a concentration of massive $\mathrm{Cu}-\mathrm{Ni}$-bearing sulfide bodies in a postulated feeder conduit. Indicated and inferred resources of the Kalatongke $\mathrm{Cu}-\mathrm{Ni}$ sulfide deposit (Fig. 5a)

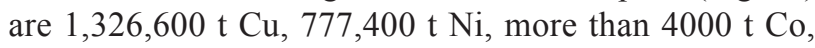
$2.5 \mathrm{t} \mathrm{Pt}$, and $3.4 \mathrm{t} \mathrm{Pd}$ (Yan et al. 2003, 2004; Han CM et al. 2007; Mao et al. 2008). The deposit is situated $15 \mathrm{~km}$ south of the Erqis Fault in the Lower Carboniferous Nanmingshui Fm. of the Puerkin-Ertai Terrane (Fig. 1) (Windley et al. 2002; Goldfarb et al. 2003; Yan et al. 2003).

Sedimentary rocks of the Nanmingshui Fm. are divided into the following three units, numbered from the lowermost upwards (Wang RM et al 1991). Unit 1 in the SW of the ore district strikes NW-SE, has a maximum apparent thickness of $\sim 200 \mathrm{~m}$ and consists of red silty sandstone, muddy slate, and tuffaceous slate intercalated with limestone and siliceous rocks. Unit 2, with a thickness of $300 \mathrm{~m}$, occurs in the central and southwestern parts of the Kalatongke mine, extends NW-SE and dips to the NE. It includes volcanosedimentary breccia, carbonaceous tuff and andesite and tuffaceous chert (Yan et al. 2003). Unit 3 is located in the central and northern parts of the Kalatongke region, where its outcrop thickness reaches a maximum of $550 \mathrm{~m}$. It consists of tuffite and carbonaceous slate with minor limestone, alkali basalt, basaltic latite and andesite.

In the Kalatongke deposit there are two sets of folds that strike NW and NWW, with the former being dominant. The southernmost anticline strikes $315^{\circ}$, extending for 2500 to $3000 \mathrm{~m}$ along strike, with symmetrical limbs dipping at $40^{\circ}$. There are four sets of faults striking NW, WNW, EW and NE respectively. The large-scale NW-striking faults have undergone multiple stages of movement and the intersections between the NW-striking and WNW-striking faults are favorable locations for the mineralized mafic-ultramafic intrusions (Wang RM et al. 1991; Yan et al. 2003). 


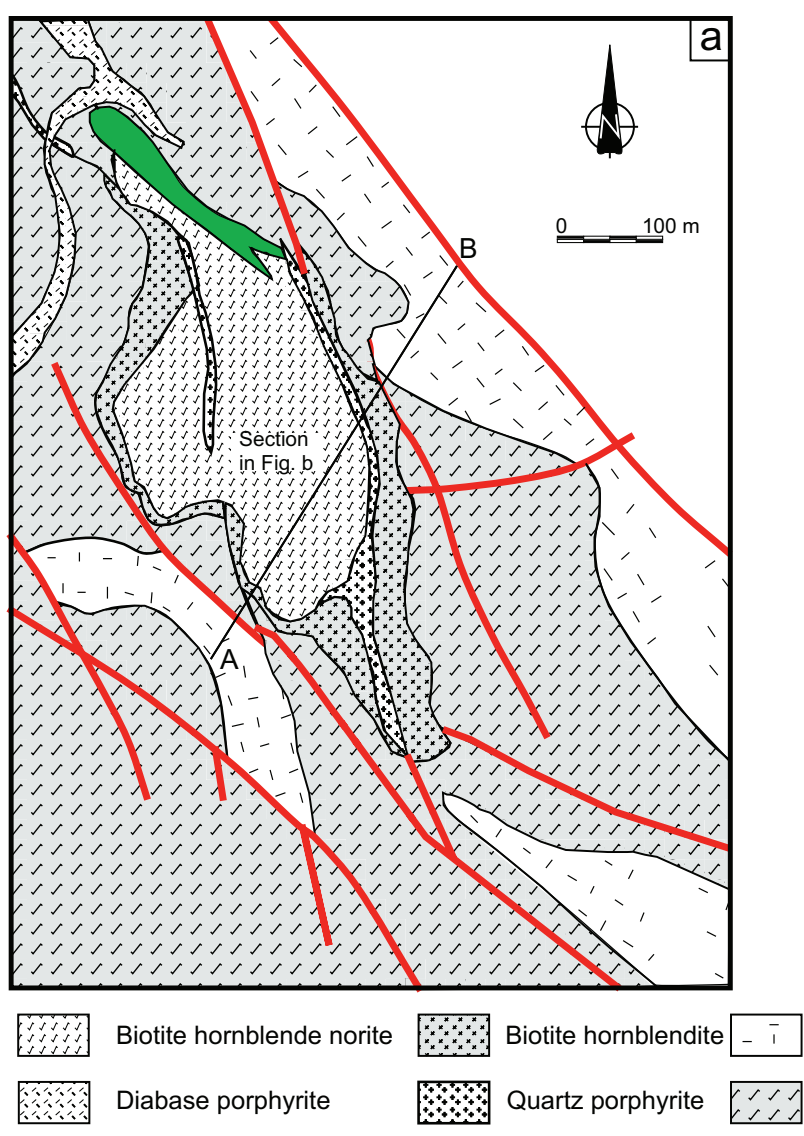

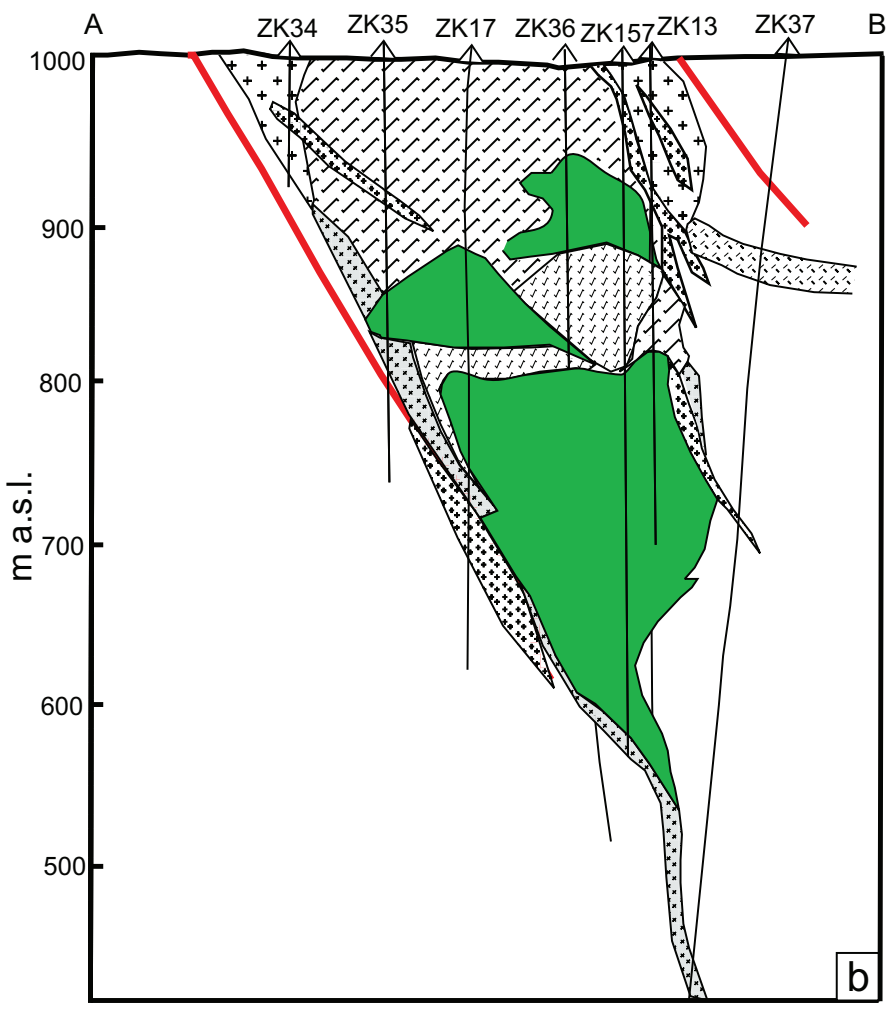

Tuff of Carboniferous Nanmingshui Fm.

Sediment-tuff of Carboniferous Nanmingshui Fm.

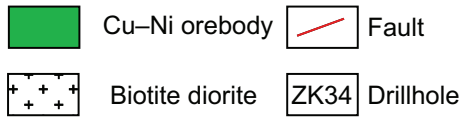

Fig. 5 Geological map of the Kalatongke Cu-Ni district (after Li et al. 1998). For location see No. 24 in Fig. 1.

Nine mafic-ultramafic intrusions were emplaced into the Lower Carboniferous Nanmingshui Fm. at the Kalatongke deposit. A well-defined differentiation sequence of lithological zones characterizes many of them. Marginal diorite grades downwards and inwards, through gabbro and norite, to a core of pyroxenite and serpentinized harzburgite (Goldfarb et al. 2003; Yan et al. 2003; Mao et al. 2008).

The Kalatongke mine has nine lenticular ore bodies, the largest of which is No 1 . In this ore body, $\mathrm{Cu}-\mathrm{Ni}$ sulfide ores are hosted in biotite-hornblende-olivine norite and biotite-hornblende norite at depths 550-1000 $\mathrm{m}$ below the surface (Fig. $5 \mathrm{~b}$ ). The ore body is oxidized from the surface to depths of more than $40 \mathrm{~m}$, and its orientation is almost parallel to that of the intrusion, which strikes $334^{\circ}$ and dips SE; the upper part dipping at 70 to $90^{\circ}$ and the lower part, 0 to $60^{\circ}$ (Fig. 5b).

More than 50 ore minerals have been reported from the Kalatongke mine (Wang et al. 1991; Han CM et al. 2007) dominated by pyrrhotite, chalcopyrite, pentlandite, violarite, pyrite and magnetite. Associated noble metalbearing minerals are melonite, michenerite, bitepalladite, sperrylite, hessite and electrum. Gangue minerals comprise mainly olivine, pyroxene, plagioclase, hornblende, biotite, chlorite and serpentinite.
The ore minerals are characterized by euhedral, subhedral, anhedral, subhedral-anhedral, porphyritic, corrosion, relict-replacement, reaction rim and skeletal crystal textures. The ore structures are mainly massive, vein, veinlet-disseminated, stockworks, or sparsely disseminated. The mineralization shows a circular zoning pattern, passing from high-grade massive ore in the center outwards to sub-economic disseminated ores.

According to the mineral assemblages and crosscutting relationships, three mineralization stages have been identified (Wang RM et al. 1991). The first assemblage, which was formed during magmatic crystallization stage, is characterized by disseminated ores containing sperrylite, violarite and magnetite. The second magmatic-hydrothermal stage resulted in the formation of massive and high grade, vein-like $\mathrm{Cu}$ and $\mathrm{Ni}$ ores, which have overprinted the disseminated ores, and contain an assemblage of $\mathrm{Cu}$ - and Ni-bearing minerals, precious metal-bearing arsenides, tellurides, and tellurobismuthides. The third stage was marked by supergene oxidation, which led to the development of a thick gossan and formation of secondary minerals such as melanterite, chalcanthite and gypsum. 


\subsection{Late Carboniferous-Early Permian skarn deposits}

Majority of the skarn deposits are of Late CarboniferousEarly Permian age, and are distributed in the QiongkuerAbagong and Puerkin-Ertai terranes. Skarn-type $\mathrm{Fe}-\mathrm{Cu}$ deposits occur in the contact (skarn) zone between intermediate-felsic intrusive rocks and carbonate sediments. The Mengku skarn-type Fe deposit lies in the middle of the Qiongkuer-Talate Terrane (Fig. 1a), which is situated in metamorphosed intermediate-felsic volcanic breccias, tuffs and marbles. The skarn-type $\mathrm{Fe}-\mathrm{Cu}$ deposits are typified by the Qiaoxiahala $\mathrm{Fe}-\mathrm{Cu}-\mathrm{Au}$ deposit in Fuyun County, with similar deposits occurring at the contact between subvolcanic (andesite porphyry) to volcanic and pyroclastic rocks. Generally, the mineralization is restricted to bedded skarns, as exemplified by the Suoerkuduke $\mathrm{Cu}-\mathrm{Mo}$ deposit in Fuyun County.

\subsubsection{Suoerkuduke Cu-Mo deposit}

The Suoerkuduke deposit is located c. $114 \mathrm{~km} \mathrm{SW}$ of the town of Fuyun. This skarn deposit was discovered in 1984 and has been mined since 2004. It is situated in the northern part of the East Junggar ore belt, and is hosted in Mid-Devonian strata of the Beitashan Fm., which locally consists of andesite, sandstone and conglomeratic tuffaceous sandstone (Fig. 6). The mine has been estimated to contain about $304500 \mathrm{t} \mathrm{Cu}$ and $13900 \mathrm{t}$ Mo based on average ore grades of $0.71 \% \mathrm{Cu}$ and $0.06 \%$ Mo (Han $\mathrm{CM}$ et al. 2006). In addition, the grade of precious metals is $3.83 \mathrm{~g} / \mathrm{t}$ while that of gold is $0.23 \mathrm{~g} / \mathrm{t}$.

The copper ores in the Suoerkuduke deposit can be divided into two types. The oxidized ores occur near the surface, typical examples being the oxidized copper ores: covellite, limonite, malachite, chrysocolla, azurite and hematite. The primary copper and molybdenum ores consist of chalcopyrite and pyrite, with subordinate sphalerite, galena, molybdenite, marcasite and pyrrhotite and minor calaverite, native gold, electrum and malachite. The principal gangue minerals are epidote, garnet, pyroxene, actinolite, calcite, chlorite, plagioclase, biotite, quartz, diopside and carbonate minerals. The ores have anhedral microgranular, anhedral inequigranular and intersertal textures and display disseminated, veinlet-disseminated and veinlet structures.

Based on field evidence and petrographic observations, four mineralization stages are distinguished: (1) prograde skarn stage (garnet, diopside and epidote), (2) retrograde skarn stage (formation of specularite, magnetite, actinolite, aedelite, plagioclase and meroxene), (3) main chalcopyrite-molybdenite stage, forming the bulk of the ore body (chalcopyrite, molybdenum, pyrrhotine, pyrite, sphalerite, galena, calcite, quartz, calcite and hematite) and (4) the supergene oxidation stage (formation of secondary minerals such as covellite, limonite, malachite, chrysocolla, azurite and hematite).
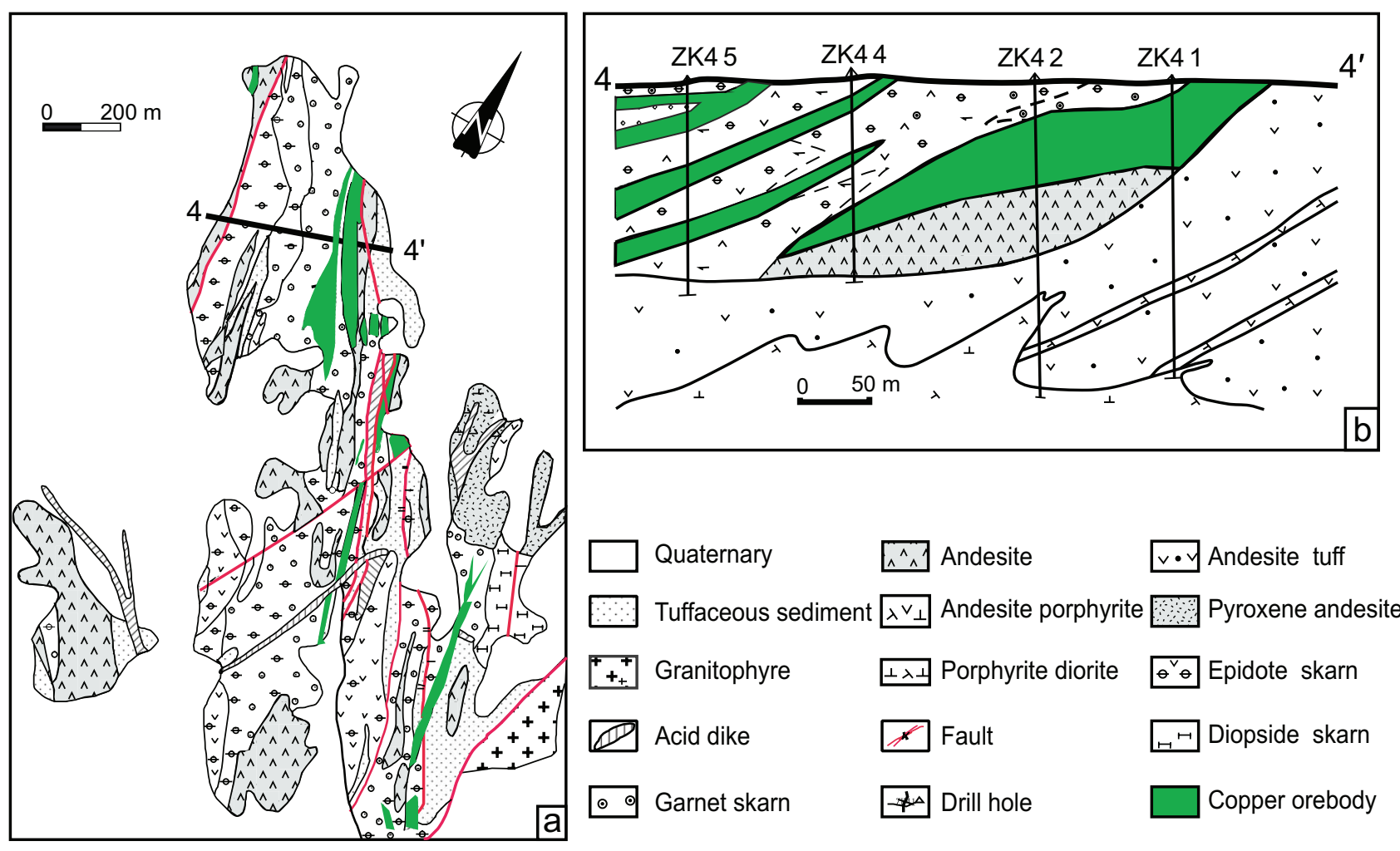

Fig. 6 Geological map of the Suoerkuduk Cu-Mo deposit (after Li et al. 1998). For location see No. 24 in Fig. 1 


\subsubsection{Qiaoxiahala Fe-Cu-Au deposit}

This deposit is located c. $23 \mathrm{~km} \mathrm{SE}$ of the town of Fuyun. It is hosted in Middle Devonian strata of the Beitashan Fm. that locally consists of andesite, tuff, sericite phyllite, calcareous-phyllite, volcanic breccia, schistose limestone and marble (Fig. 7). The deposit contains about $4,620,000 \mathrm{t}$ of $\mathrm{Fe}$ ore and 17,600 $\mathrm{t}$ of $\mathrm{Cu}$ based on average ore grades of $35.05 \% \mathrm{Fe}$ and $0.80 \% \mathrm{Cu}$. The deposit also contains other minor metals such as $\mathrm{Co}, \mathrm{Ni}$ and $\mathrm{Ag}$ (Wang DH et al. 2002).

There are more than ten $\mathrm{Fe}-\mathrm{Cu}$ ore bodies that are up to $5000 \mathrm{~m}$ long, $10-70 \mathrm{~m}$ wide, and $>500 \mathrm{~m}$ deep. They are composed of disseminated $\mathrm{Fe}$ and $\mathrm{Cu}$ ores, as well as banded and massive Fe ores. The ore minerals are predominantly magnetite, chalcopyrite, hematite, iron glance, bornite, pyrrhotite; the gangue minerals are garnet, epidote, chlorite, calcite, quartz and biotite. Wall-rock alteration related to $\mathrm{Fe}-\mathrm{Cu}$ mineralization in the Qiaoxiahala mine mainly includes skarn formation, chloritization, epidotization and carbonation.
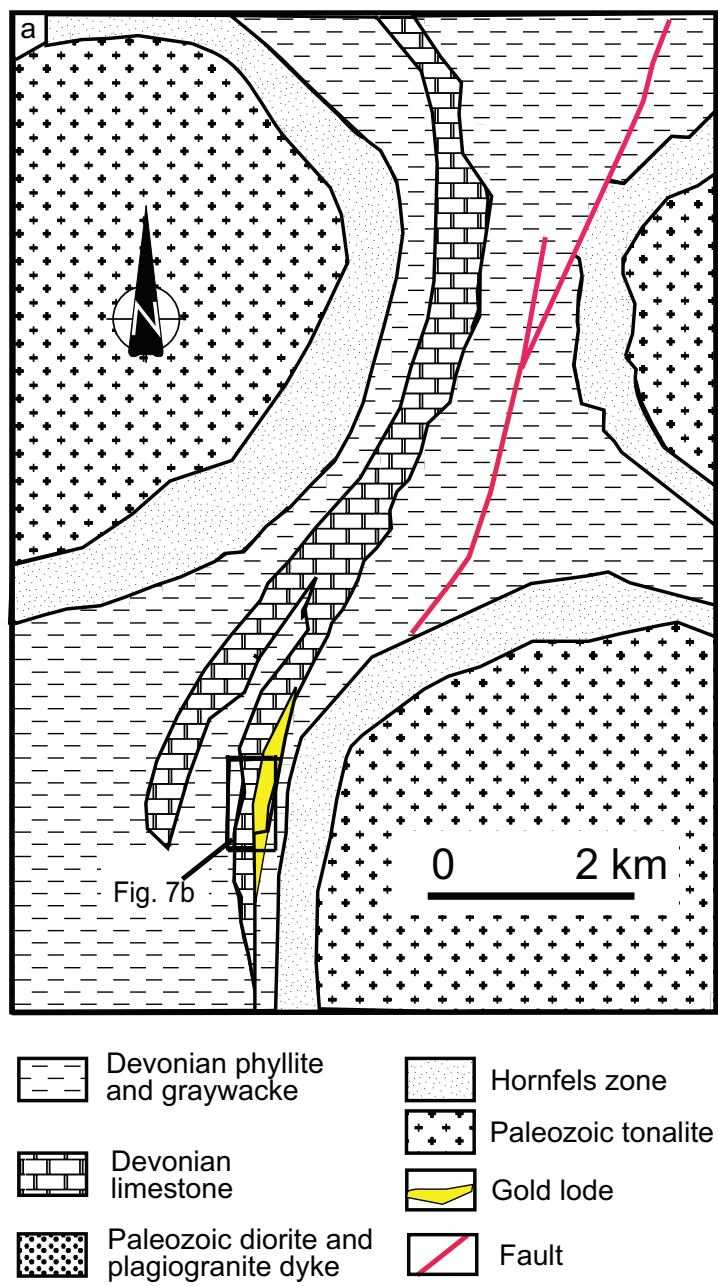

Devonian phyllite and graywacke

Devonian limestone

Paleozoic diorite and plagiogranite dyke
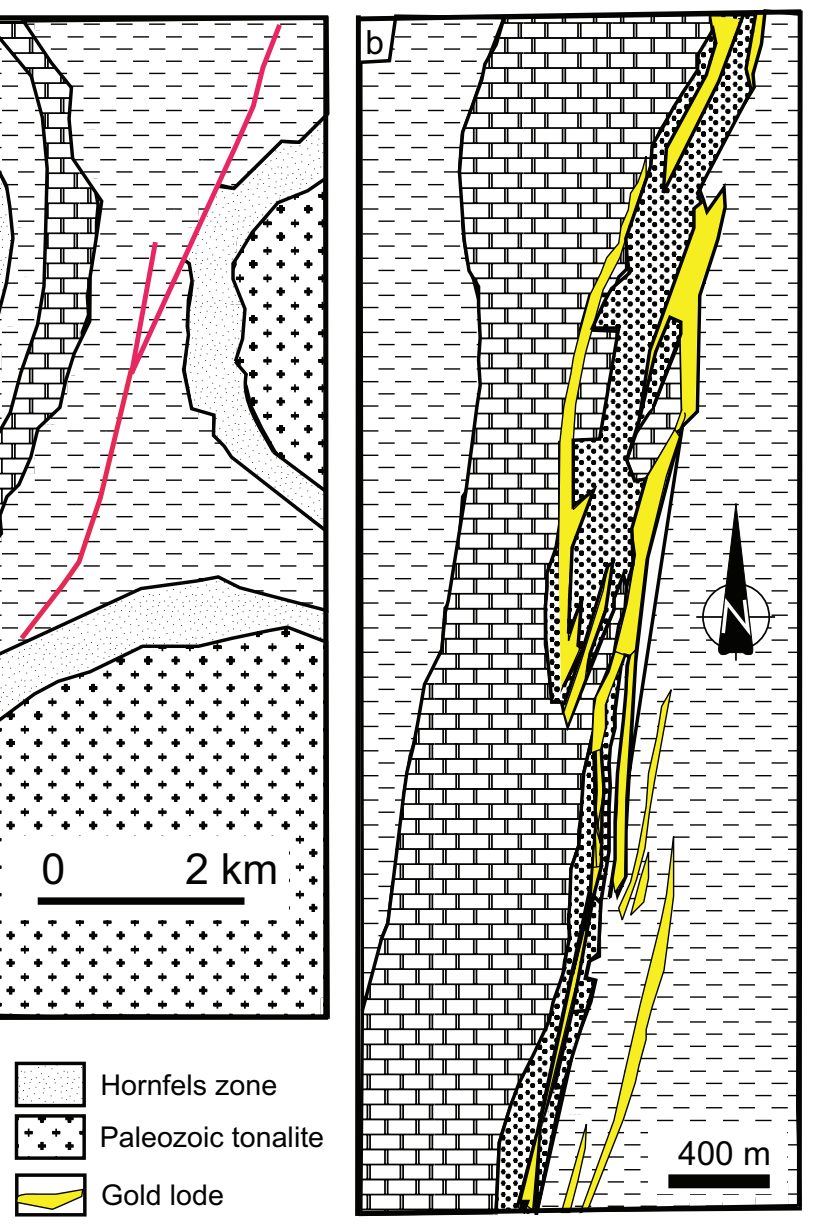

Fig. 7 Geology of the Duolanasayi orogenic gold deposit, Chinese Altai Shan (after Rui et al. 2002). For location see No. 14 in Fig. 1.
Orogenic gold deposits in the Altai show a clear spatial association with faults (Goldfarb et al. 2003), marked specifically by the Tuergen-Hongshanzui, Erqis and Aermantai faults.

\subsubsection{Duolanasayi gold deposit}

This deposit is situated $52 \mathrm{~km}$ NW of the town of Habahe. It was discovered in 1987, and mining began in 1989 . The deposit occurs in a shear zone cutting the Mid-Devonian Tuokesalei Fm., which locally 

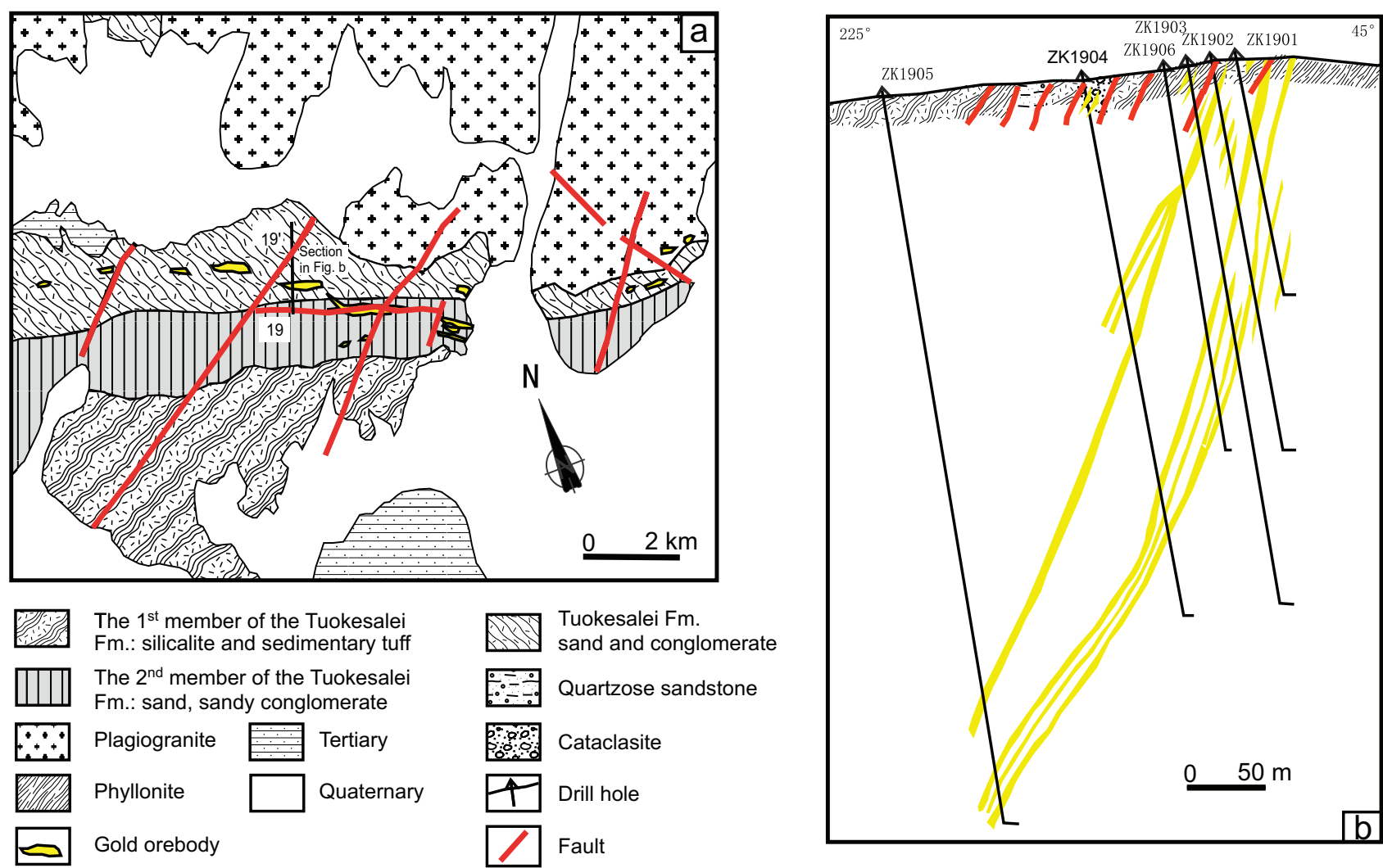

Fig. 8 Geological map of the Saidu Au deposit (after Wang DH et al. 2002). For location see No. 13 in Fig. 1.

consists of phyllite, graywacke and limestone (Fig. 8). Several $289 \pm 5 \mathrm{Ma}$ (SHRIMP zircon U-Pb dating, Li et al. 1998) tonalite dikes occur in the area. The deposit comprises a number of mineralized bodies that occur in a $20 \times 10 \mathrm{~km}$ zone between the Maerkakuli and Habahe $\mathrm{N}-\mathrm{S}$ trending second-order faults (Rui et al. 2002; Wang $\mathrm{DH}$ et al. 2002). The Au reserve is estimated to be $c .30$ $\mathrm{t}$ with an average of $8.3 \mathrm{~g} / \mathrm{t}$ (Rui et al. 2002).

The gold ores in the Duolanasayi deposit are grouped into two types. The oxidized ores are native gold, limonite, hematite, covellite, digenite, chalcocite, psilomelane, pyrolusite, jarosite, and gypsum. The primary ores occur in disseminated altered rocks and auriferous quartz-sulfide veins or veinlets. Principal minerals associated with the disseminated altered rocks include native gold, pyrite, chalcopyrite, pyrrhotite, galena, with minor molybdenite, magnetite and tetrahedrite. The auriferous quartz-sulfide vein ores are composed mainly of massive quartz, and minor albite, ankerite, calcite, chlorite, pyrite, chalcopyrite, galena, molybdenite, sphalerite and native gold. The sulfide and gold minerals exhibit disseminated, massive and veinlet structures in quartz fractures.

Wang Z (1991) divided auriferous hydrothermal activity at the Duolanasayi deposit into four stages: (1) early pyrite-quartz-scheelite, (2) pyrite-chalcopyrite-sphalerite-galena-quartz, (3) quartz-dolomite-calcite, and (4) late quartz-jarosite-limonite-gypsum. Although all the four stages were involved in the deposition of gold, the first two are the most important, whereas the fourth stage led to the enrichment of gold in the oxidized zones.

Wang Z (1991) showed that the $\delta^{34} \mathrm{~S}$ composition of pyrite in the ore in the Duolanasayi deposit ranges from -8.8 to $+1.4 \%$, with a mean of $-2.9 \%$, suggesting that the sulfur had a deep crustal or upper mantle source, and that mixing with upper crust was part of the ore-forming process (Liu YL et al. 2003).

\subsubsection{Shaerbulake gold deposit}

This deposit is located c. $32 \mathrm{~km} \mathrm{SW}$ of Fuyun (Fig. 1). This shear zone-hosted gold deposit was discovered in 1986, but mining commenced in 1989. The deposit is hosted in the Lower Carboniferous Nalinkala Fm., which consists of phyllite, siltstone, tuffaceous sandy conglomerate and limestone. The ore deposit occurs in a $18 \times 2 \mathrm{~km}$ zone along the NW-trending Saerbulake Fault (Wang DH et al. 2002). It is estimated to contain $c .10 \mathrm{t} \mathrm{Au}$ and an average Au grade of $6 \mathrm{~g} / \mathrm{t}$ (Rui et al. 2002).

Principal metallic minerals include native gold, electrum, pyrite, arsenopyrite and pyrrhotite. The gangue minerals are quartz, albite, sericite, and ankerite. The ores are characterized by euhedral, subhedral and pseudomorphic textures, while the structures include dissemination, veinlet-dissemination and brecciation ones. The ore 
bodies are vein-shaped and hosted in NW-SE sheared alteration zones that strike.

Five mineralization stages can be distinguished (Wang DH et al. 2002): (1) early quartz-arsenopyrite, (2) pyritequartz, (3) quartz-dolomite-calcite, (4) quartz-albite and (5) late jarosite-limonite-gypsum.

\subsubsection{Saidu gold deposit}

This deposit is situated NE of Habahe (Fig. 1). It is hosted in the Lower to Middle Devonian Tuokesalei Fm. that consists of sandstone, limestone and pelite. The deposit consists of a number of mineralized bodies occupying an area of $18 \times 2 \mathrm{~km}$ along the Maerkakuli Fault (Liu YL et al. 2003). Gold ores are concentrated in four groups that occur in an area of c. $4 \times 1 \mathrm{~km}$ (Liu YL et al. 2003).

The Saidu ore bodies include auriferous quartz veins, altered dikes, and altered clastic rocks. The gold ores are divided into two types: oxidized and primary. The sulfides and oxides include pyrite, chalcopyrite, pyrrhotite, magnetite, hematite, galena, sphalerite, marcasite, molybdenite, ilmenite and rutile. Four paragenetic stages can be identified: (1) magnetite-quartz, (2) pyrite-quartz, (3) sulfide-native gold-quartz, and (4) quartz-carbonate.

\section{Discussion}

\subsection{Geochronological data for ore deposits}

Based on their geochronological data (Tab. 3), the mineral deposits in the Chinese Altai can be classified into three groups: (i) pre-accretionary VMS deposits (c. 380$360 \mathrm{Ma}$ ) and porphyry $\mathrm{Cu}-\mathrm{Mo}$ deposit (c. 370-330 Ma), (ii) syn-to post-accretionary magmatic $\mathrm{Cu}-\mathrm{Ni}$ deposits and skarn $\mathrm{Cu}-\mathrm{Mo}$ deposit (c. $304 \mathrm{Ma}$ ) that formed in Late Carboniferous to Early Permian (c. 305-285 Ma) and (iii) syn-to post-accretionary orogenic gold lodes (c. 290-280 Ma).

The hanging wall of the principal Ashele orebody (No. 1) is an Ashele Fm. tuff that yielded a concordant zircon $\mathrm{U}-\mathrm{Pb}$ age of $387.0 \pm 4.2 \mathrm{Ma}$, whereas the footwall basalt gave a weighted average ${ }^{206} \mathrm{~Pb} /{ }^{238} \mathrm{U}$ age of $388.0 \pm 3.3 \mathrm{Ma}$ (Yang FQ et al. 2014). The two ages indicate that the principal orebody of the Ashele $\mathrm{Cu}-\mathrm{Zn}$ deposit formed during the Mid-Devonian, at around $388 \mathrm{Ma}$ (Tab. 3).

In the Devonian Ashele Fm., the iron jaspers gave a $\mathrm{Rb}-\mathrm{Sr}$ isochron age of $378 \pm 39 \mathrm{Ma}$ and a $\mathrm{Sm}-\mathrm{Nd}$ isochron age of $373 \pm 14 \mathrm{Ma}$ (Li HQ et al. 1998). From the Ashele deposit, the following $\mathrm{Rb}-\mathrm{Sr}$ isochron ages were obtained; laminated chalcopyrite $(364 \pm 15 \mathrm{Ma})$, pyritequartz veins $(302 \pm 11 \mathrm{Ma})$, and tetrahedrite-bearing car- bonate-quartz veins $(255 \pm 16 \mathrm{Ma})$, whereas the blendes gave $\mathrm{Rb}-\mathrm{Sr}$ and $\mathrm{Sm}-\mathrm{Nd}$ isochron ages of $265 \pm 8 \mathrm{Ma}$ and 282 \pm 11 Ma respectively (Li HQ et al. 1998; Wang $\mathrm{DH}$ et al. 2002). Taken together, the Ashele VMS Cu- Zn deposit may have undergone a protracted mineralization history, although the main phase of mineralization took place in the Devonian. Hydrothermal alteration in the Carboniferous-Permian probably modified and upgraded the deposit.

Sphalerites in the ores of Keketale gave a $\mathrm{Sm}-\mathrm{Nd}$ isochron age of $373 \pm 15 \mathrm{Ma}$, while $\mathrm{Rb}-\mathrm{Sr}$ isochron age dating of the blendes yielded $274 \pm 8 \mathrm{Ma}$ (Li HQ et al. 1998). The former represents the mineralization age of the Keketale $\mathrm{Pb}-\mathrm{Zn}$ deposit, whereas the latter reflects reworking during a late thermal event. This suggests that the deposit experienced a protracted or two-stage thermal history.

SHRIMP U-Pb zircon ages of $381 \pm 6 \mathrm{Ma}$ and $375 \pm 9$ Ma were obtained for a mineralized granodiorite porphyry and $\mathrm{Re}-\mathrm{Os}$ isochron ages of $378 \pm 6 \mathrm{Ma}$ and $374 \pm 2$ Ma for molybdenites from the Xileketashihalasu porphyry $\mathrm{Cu}$ deposit (Zhang ZC et al. 2006; Wu et al. 2008; Yang FQ et al., 2010). Zhao ZF et al. (2009) dated the Yulekenhalasu porphyritic granite by a LA-ICP-MS zircon $\mathrm{U}-\mathrm{Pb}$ method at $381.6 \pm 2.5 \mathrm{Ma}$, for which Yang FQ et al. (2012) have obtained a molybdenite Re-Os isochron age of $373.9 \pm 2.2 \mathrm{Ma}$ (Tab. 3).

Wang YW et al. (2010) presented a Re-Os isochron age of $327.1 \pm 2.9 \mathrm{Ma}$ for molybdenites of the Xilekuduke, for which Long LL et al. (2010) have published a LA-ICP-MS zircon U-Pb age of $329.3 \pm 2.3 \mathrm{Ma}$.

Olivine norite, norite, hybrid norite and diabase-gabbro from the Kalatongke $\mathrm{Cu}-\mathrm{Ni}$ deposit gave $\mathrm{Rb}-\mathrm{Sr}$ isochron ages of $285 \pm 16 \mathrm{Ma}, 298 \pm 23 \mathrm{Ma}, 302 \pm 32 \mathrm{Ma}$ and $317 \pm 50$ Ma respectively (Wang RM et al. 1991). Similarly, the $\mathrm{Cu}-\mathrm{Ni}$-bearing mafic-ultramafic rocks were dated by the SHRIMP U-Pb method on zircon at $287 \pm 5$ $\mathrm{Ma}$ (Han BF et al. 2004). Accordingly, we suggest that the emplacement age of the Kalatongke intrusion ranges between 298 and $285 \mathrm{Ma}$. In addition, the massive and densely disseminated sulfide ores from the Kalatongke $\mathrm{Cu}-\mathrm{Ni}$ deposit yielded a $\mathrm{Sm}-\mathrm{Nd}$ isochron age of $281 \pm 12$ Ma (Li HQ et al. 1998), whilst Re-Os age dating of the Kalatongke No. 1 deposit gave $305 \pm 15$ Ma (Han CM et al. 2007). In summary, these isotopic data indicate that the Kalatongke mafic-ultramafic intrusion and its associated $\mathrm{Cu}-\mathrm{Ni}$ deposit formed in the Late Carboniferous-Early Permian.

In the Suoerkudouke area, altered (pyroxene) andesite, and its porphyry gave a whole-rock $\mathrm{Rb}-\mathrm{Sr}$ isochron age of $288 \pm 18 \mathrm{Ma}$ (Li HQ et al. 1998), which is comparable to a $\mathrm{Rb}-\mathrm{Sr}$ isochron age of $274.0 \pm 1.1 \mathrm{Ma}$ for the andesite (Hu et al. 1993). On the other hand, garnet and epidote in the ore-bearing skarns in the Suoerkuduke deposit have 
Tab. 3 Available geochronological data for ore deposits in the Chinese Altai

\begin{tabular}{|c|c|c|c|c|}
\hline Name of deposit & Dated minerals/rocks & Dating method & Age (Ma) & Data sources \\
\hline Ashele $\mathrm{Cu}-\mathrm{Zn}$ & Tuff & LA-ICP-MS zircon U-Pb & $387.0 \pm 4.2$ & Yang FQ et al. (2014) \\
\hline " & Basalt & LA-ICP-MS zircon U-Pb & $388.0 \pm 3.3$ & Yang FQ et al. (2014) \\
\hline$"$ & Iron jasper & $\mathrm{Rb}-\mathrm{Sr}$ isochron & $378 \pm 39$ & Li HQ et al. (1998) \\
\hline$"$ & Iron jasper & $\mathrm{Sm}-\mathrm{Nd}$ isochron & $373 \pm 14$ & Li HQ et al. (1998) \\
\hline$"$ & Chalcopyrite & $\mathrm{Rb}-\mathrm{Sr}$ isochron & $364 \pm 15$ & Li HQ et al. (1998) \\
\hline$"$ & Quartz-pyrite & $\mathrm{Rb}-\mathrm{Sr}$ isochron & $302 \pm 11$ & Li HQ et al. (1998) \\
\hline$"$ & Carbonate-quartz & $\mathrm{Rb}-\mathrm{Sr}$ isochron & $255 \pm 16$ & Li HQ et al. (1998) \\
\hline$"$ & Blende & $\mathrm{Rb}-\mathrm{Sr}$ isochron & $265 \pm 8$ & Wang DH et al. (2002) \\
\hline$"$ & Blende & $\mathrm{Sm}-\mathrm{Nd}$ isochron & $282 \pm 11$ & Wang DH et al. (2002) \\
\hline Keketale $\mathrm{Pb}-\mathrm{Zn}$ & Sphalerite & $\mathrm{Sm}-\mathrm{Nd}$ isochron & $373 \pm 15$ & Li HQ et al. (1998) \\
\hline " & Blende & $\mathrm{Rb}-\mathrm{Sr}$ isochron & $274 \pm 8$ & Li HQ et al. (1998) \\
\hline Xileketashihalasu $\mathrm{Cu}$ & Granodiorite porphyry & SHRIMP zircon $\mathrm{U}-\mathrm{Pb}$ & $381 \pm 6$ & Zhang ZC et al. (2006) \\
\hline$"$ & Granodiorite porphyry & SHRIMP zircon U-Pb & $375 \pm 9$ & Wu et al. (2008) \\
\hline$"$ & Molybdenite & $\mathrm{Re}-\mathrm{Os}$ isochron & $378 \pm 6$ & Yang FQ et al. (2010) \\
\hline " & Molybdenite & $\mathrm{Re}-\mathrm{Os}$ isochron & $374 \pm 2$ & Wu et al. (2008) \\
\hline Yulekenhalasu $\mathrm{Cu}$ & Porphyrite granite & LA-ICP-MS zircon U-Pb & $381.6 \pm 2.5$ & Zhao ZF et al. (2009) \\
\hline " & Molybdenite & $\mathrm{Re}-\mathrm{Os}$ isochron & $373.9 \pm 2.2$ & Yang FQ et al. (2012) \\
\hline Xilekuduke $\mathrm{Cu}-\mathrm{Mo}$ & Enclaves in granodiorite & LA-ICP-MS zircon U-Pb & $329.3 \pm 2.3$ & Long LL et al. (2010) \\
\hline " & Molybdenite & $\mathrm{Re}-\mathrm{Os}$ isochron & $327.1 \pm 2.9$ & Wang YW et al. (2010) \\
\hline Kalatongke $\mathrm{Cu}-\mathrm{Ni}$ & Olivine norite & $\mathrm{Rb}-\mathrm{Sr}$ isochron & $285 \pm 16$ & Wang RM et al. (1991) \\
\hline " & Norite & $\mathrm{Rb}-\mathrm{Sr}$ isochron & $298 \pm 23$ & Wang RM et al. (1991) \\
\hline$"$ & Hybrid norite & $\mathrm{Rb}-\mathrm{Sr}$ isochron & $302 \pm 32$ & Wang RM et al. (1991) \\
\hline$"$ & Diabase gabbro & $\mathrm{Rb}-\mathrm{Sr}$ isochron & $317 \pm 50$ & Wang RM et al. (1991) \\
\hline$"$ & Biotite norite & SHRIMP zircon $\mathrm{U}-\mathrm{Pb}$ & $287 \pm 5$ & Han BF et al. (2004) \\
\hline & $\mathrm{Cu}-\mathrm{Ni}$ ores & Sm-Nd isochron & $281 \pm 12$ & Li HQ et al. (1998) \\
\hline$"$ & Sulfides & $\mathrm{Re}-\mathrm{Os}$ isochron & $305 \pm 15$ & Han CM et al. (2007) \\
\hline Suoerkuduke skarn Cu-Mo & Porphyry & $\mathrm{Rb}-\mathrm{Sr}$ isochron & $288 \pm 18$ & Li HQ et al. (1998) \\
\hline " & Andesite & $\mathrm{Rb}-\mathrm{Sr}$ isochron & $274.0 \pm 1.1$ & Hu et al. (1993) \\
\hline$"$ & Garnet, epidote & $\mathrm{Sm}-\mathrm{Nd}$ isochron & $284.3 \pm 3.9$ & Li HQ et al. (1998) \\
\hline$"$ & Molybdenite & $\mathrm{Re}-\mathrm{Os}$ isochron & $304.7 \pm 7.3$ & Wan et al. (2014) \\
\hline Duoalnasayi Au & Quartz, fluid inclusions & $\mathrm{Rb}-\mathrm{Sr}$ isochron & $269 \pm 13$ & Li HQ et al. (1998) \\
\hline " & Muscovite & Ar-Ar plateau & $292.8 \pm 1.0$ & Yan et al. (2004) \\
\hline " & Muscovite & $\mathrm{Ar}-\mathrm{Ar}$ isochron & $293.1 \pm 4.8$ & Yan et al. (2004) \\
\hline Saerbulake Au & Granite & SHRIMP zircon U-Pb & $410 \pm 4$ & Liu F et al. (2010) \\
\hline Saidu Au & Muscovite & $\mathrm{Ar}-\mathrm{Ar}$ isochron & $291.3 \pm 8.4$ & Yan et al. (2004) \\
\hline$"$ & Muscovite & Ar-Ar plateau & $289.2 \pm 3.1$ & Yan et al. (2004) \\
\hline$"$ & Quartz, fluid inclusions & $\mathrm{Rb}-\mathrm{Sr}$ isochron & $306 \pm 7$ & Li HQ et al. (1998) \\
\hline$"$ & Quartz, fluid inclusions & $\mathrm{Rb}-\mathrm{Sr}$ isochron & $272 \pm 19$ & Li HQ et al. (1998) \\
\hline
\end{tabular}

a Sm-Nd isochron age of $284.3 \pm 3.9 \mathrm{Ma}$ (Li HQ et al. 1998). Recently, Wan et al. (2014) presented a Re-Os isochron age of $304.7 \pm 7.3 \mathrm{Ma}$ for molybdenites of the Suoerkudouke.

Other geochronological studies have also produced different ages. For example, Li HQ et al. (1998) reported $\mathrm{Rb}-\mathrm{Sr}$ ages of $269 \pm 13 \mathrm{Ma}$ for fluid inclusions in mineralized quartz from the Duolanasayi gold deposit and of $306 \pm 7$ to $272 \pm 19$ Ma for those from the Saidu gold deposit. Yan et al. (2004) also obtained an Ar-Ar plateau age of $292.8 \pm 1.0 \mathrm{Ma}$ and an isochron age of $293.1 \pm 4.8$ Ma for muscovite from the Duolanasayi deposit, and Ar-Ar plateau age of $289.2 \pm 3.1 \mathrm{Ma}$ and isochron age of $291.3 \pm 8.4 \mathrm{Ma}$ for muscovite from the Saidu gold deposit.

\subsection{Metallogenic evolution of the Chinese Altai Shan}

The Chinese Altai occupies a key position within the Central Asian belts (Hu et al. 2000; Xiao et al. 2004), and its geodynamic evolution was closely associated with that of the CAOB. Most terranes were developed by subductionrelated processes and accreted in a southward direction from the Cambrian (e.g. Habahe Grp.) to the Permian (e.g. Kuerti Fm.). Lateral growth of the southern Chinese Altai indicates a massive addition of juvenile material to the Paleozoic crust (Şengör et al. 1993; Xiao et al. 2004).

The Late Carboniferous-Early Permian Chinese Altai island arc contains subduction-generated adakites and boninites (Xiao et al. 2004) and the presence of Alaskan- 
type mafic-ultramafic complexes (Laurent-Charvet et al. 2002; Han CM et al. 2007) suggests that the southern Altai developed in a subduction-accretion setting in the Late Carboniferous-Early Permian (Xiao et al. 2004). The Kalatongke mafic-ultramafic intrusion was previously considered as having formed in a post-orogenic extensional setting in the Late Carboniferous-Early Permian (Wang JB et al. 2003). However, the most recent $\mathrm{Re}-\mathrm{Os}$ geochronological and geochemical results indicate that this intrusion, along with the $\mathrm{Cu}-\mathrm{Ni}$ deposit, was produced by subduction-accretion of oceanic crust.

In the southern Altai, southwest-directed rollback and associated slab-detachment occurred during the Devonian (400 to $370 \mathrm{Ma}$ ) in response to a later addition to the collision zone at the accreting continental margin (Fig. 9a; $X i a o$ et al. 2004). Mafic and alkalic igneous activity associated with different types of mineralization occurred in the Kelang Basin during this backarc extensional event, which was possibly associated with the upwelling of the asthenosphere (Fig. 9b). Thus the slab rollback not only triggered the backarc extension but also provided a heat source for the partial melting that initiated the Middle Devonian felsic magmatism. The upwelling of the asthenosphere also could have yielded hydrothermal fluids that led to the VMS Cu-Pb-Zn mineralization (Fig. 9b), a process analogous to the Pliocene tectonic setting in Fiji following the collision of the Ontong Java Plateau with the Melanesian Arc (Han CM et al. 2006).

In our model, the development of the mineralized granodiorite porphyry complexes was associated with northdipping subduction-accretion, which led to the formation of the southern part the Dulate-Baytag Arc, as evidenced by the presence of adakites (Yang WP et al. 2005). In the Middle Devonian-Early Carboniferous, the northwarddipping subduction of an oceanic slab is thought to have resulted in the formation of a magmatic arc in the southern Altai and East Junggar. At the leading edge on the upper plate, these complexes initially experienced adakitic magmatism in response to the partial melting of slab material. Opening a slab window beneath these complexes could have led to multiple pulses of magmatism and production of crustal melts (Thorkelson and Breitsprecher 2005).

Concentrically zoned mafic-ultramafic intrusions, similar to those in the Alaskan-type belts, developed from Late Carboniferous to Early Permian in the Dulate Arc, north of the Erqis Terrane. They were accreted to the Siberian continental margin during the earliest Permian subduction-accretion. The identical ages of the magmatic $\mathrm{Cu}-\mathrm{Ni}$ sulfide and $\mathrm{Cu}-\mathrm{Mo}-\mathrm{Fe}$ skarn deposits suggest that they were all linked to the final stages of terrane accretion and related subduction magmatism (Xiao et al. 2008; Fig. 9c).

During the Late Carboniferous to Early Permian, the Chinese Altai was transformed into a continental magmatic arc in which an extensive lode gold mineralization occurred throughout the accreted margin (Fig. 9c). Late Carboniferous to Early Permian subduction-related plutonism within the Erqis Terrane, the autochthonous rocks occurring in the Puerkin-Ertai Terrane to the south, resulted in the development of a major gold province in the southern Altai, and the formation of gold-quartz veins in the Erqis and Puerkin-Ertai terranes from 305 to $270 \mathrm{Ma}$ (Goldfarb et al. 2003). The upper greenschist to amphibolite-facies dehydration reactions were probably responsible for the production of the appropriate vein-forming fluids.

\section{Conclusions}

The mineral deposits in the Chinese Altai-East Junggar can be categorized into five major types: (1) Devonian VMS $\mathrm{Cu}-\mathrm{Pb}-\mathrm{Zn}$ deposits, (2) Early Carboniferous porphyry-type $\mathrm{Cu}-\mathrm{Au}$ deposits, (3) Late CarboniferousEarly Permian Alaskan-type $\mathrm{Cu}-\mathrm{Ni}$-PGE sulfide deposits, (4) Late Carboniferous-Early Permian skarn-type $\mathrm{Cu}-\mathrm{Mo}-\mathrm{Fe}$ deposits and (5) Late Carboniferous to Early Permian orogenic-type Au deposits.

The presence of VMS $\mathrm{Cu}-\mathrm{Pb}-\mathrm{Zn}$ deposits generally points to a long-lived subduction-accretion and growth by forearc accretion, following the model of forearc accretion in Japan. The Devonian accretion and associated slab-tearing probably triggered the slab rollback, crustal thinning and asthenospheric upwelling, which could have provided the heat for mineralization associated with the VMS $\mathrm{Cu}-\mathrm{Pb}-\mathrm{Zn}$ mineralization.

From the Late Devonian to Early Carboniferous, the north-dipping subduction beneath the Dulate Arc led to the genesis of subduction-related porphyry $\mathrm{Cu}-\mathrm{Au}$ deposits. From the Late Carboniferous to Early Permian, syn-to post-accretionary $\mathrm{Cu}, \mathrm{Ni}$ and $\mathrm{Au}$ deposits developed in association with a series of subduction, convergent and delamination events, leading to the formation of $\mathrm{Cu}, \mathrm{Ni}$ and Au mineralization restricted to the southern Chinese Altai.

Acknowledgements. We are indebted to Xianhua Li, Kezhang Qin and Lianchang Zhang for thoughtful discussions, which improved and initiated many of the ideas in this paper. We are grateful to Emil Jelínek for his constructive discussions and comments on an early version of the manuscript, which led to substantial improvements of the paper. This study was financially supported by funds from the National Natural Science Foundation Projects $(41190075,41230207,41272107)$, the National 305 Projects (2011BAB06B04-1), the Chinese State 973 projects (2014CB440801, 2007CB411307), and Hong Kong RGC (7066/07P). This paper is a contribution to IGCP 592. 


\section{A Late Ordovician to Silurian}

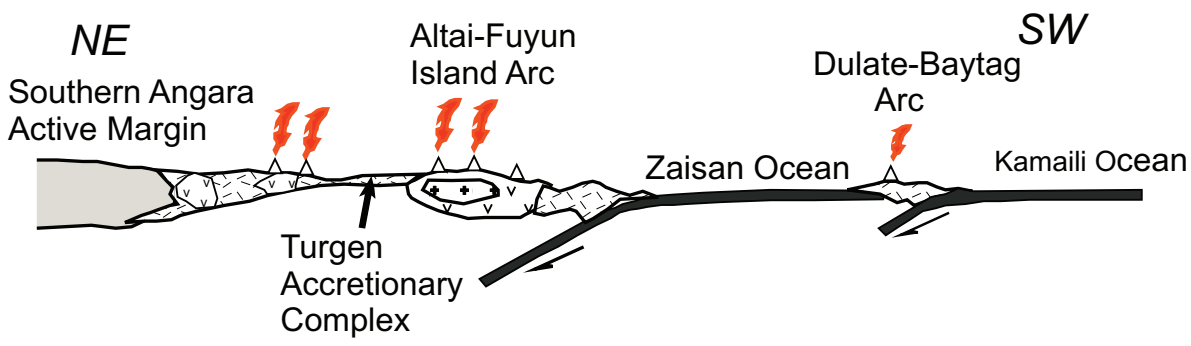

B Early Devonian to Late Carboniferous

$N E$

SW

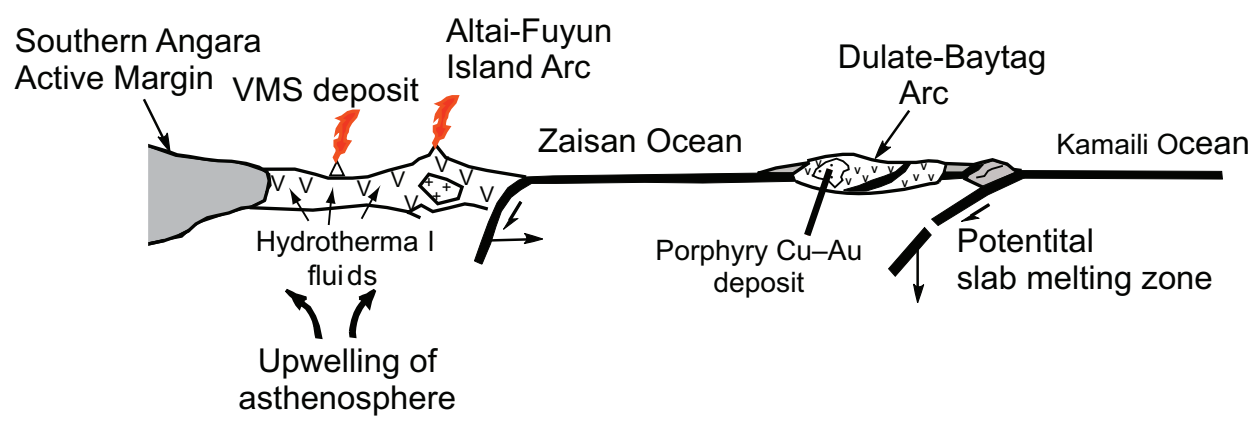

C Late Carboniferous to Early Permian

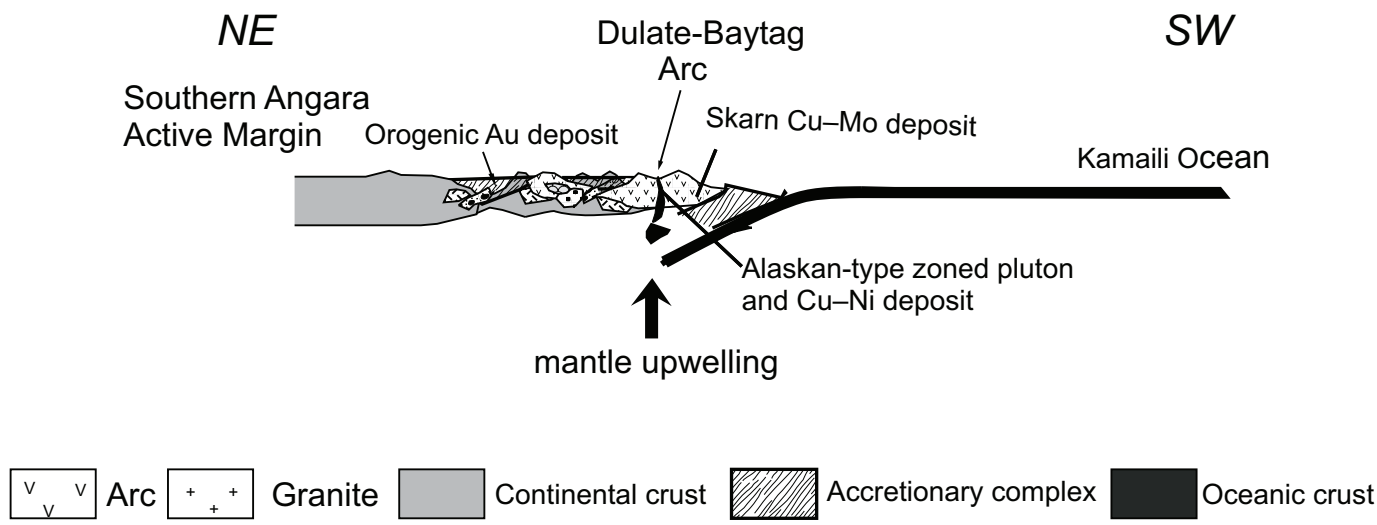

Fig. 9 Schematic diagrams showing the late Paleozoic evolution and the formation of metal deposits in the Chinese Altai (after Xiao et al. 2004; Han $\mathrm{CM}$ et al. 2006). See text for discussion.

\section{References}

Badarch G, Cunningham WD, Windley BF (2002) A new terrane subdivision for Mongolia: implications for the Phanerozoic crustal growth of Central Asia. J Asian Earth Sci 21: 87-110

Briggs SM, Yin A, Manning CE, Chen ZL, Wang XF, Grove M (2007) Late Paleozoic tectonic history of the
Ertix Fault in the Chinese Altai and its implications for the development of the Central Asian Orogenic System. Geo Soc Am Bull 119: 944-960

Buslov MM, Saphonova IY, Watanabe T, Obut OT, Fujiwara Y, Iwata K, Semakov NN, Sugai Y, Smirnova LV, Kazansky AY, Itaya T (2001) Evolution of the Paleo-Asian Ocean (Altai-Sayan, Central Asia) and collision of possible Gondwana-derived terranes with the 
southern marginal part of the Siberian continent. Geosci J 5: 203-224

Buslov MM, Watanabe T, Fujiwara Y, Iwata K, Smirnova LV, Safonova IY, Semakov NN, Kiryanova AP (2004) Late Paleozoic faults of the Altai region, Central Asia: tectonic pattern and model of formation. J Asian Earth Sci 23: 655-671

Chen YC, Ye QT, Feng J, Mu CL, Zhou LR, Wang QM, Huang GZ, Zhuang DZ, Ren BC (1996) Ore-forming Conditions and Metallogenic Prognosis of the Ashele Copper-Zinc Metallogenic Belt, Xinjiang, China. Geological Publishing House, Beijing, pp 1-330 (in Chinese)

Dobretsov NL, Berzin NA, Buslov MM (1995) Opening and tectonic evolution of the Paleo-Asian Ocean. Int Geol Rev 37: 335-360

D'yachkov BA, Titov DV, Sapargaliev EM (2009) Ore belts of the Greater Altai and their ore resource potential. Geol Ore Depos 51: 197-211

Fedorovski VS, Khain EV, Vladimirov AG, KarGopolov SA, Gibsher AS, Izokh AE (1995) Tectonics, metamorphism, and magmatism of collisional zones of the Central Asian Caledonides. Geotectonics 29: 193-212

Goldfarb RJ, Mao JW, Seltmann R, Wang DH, Xiao WJ, HART C (2003) Tectonic and metallogenic evolution of the Altai Shan, Northern Xinjiang Uygur Autonomous region, Northwestern China. In: MaO JW, GoldFarb RJ, Seltmann R, Wang DH, Xiao WJ, Hart C (eds) Tectonic Evolution and Metallogeny of the Chinese Altai and Tianshan. Proceeding Volume of the International Symposium of the IGCP-473 Project in Urumqi, pp 17-30

Han BF, Wang SG, Jahn BM, Hong DW, Kagami H, Sun YL (1997) Depleted-mantle source for the Ulungur River A-type granites from North Xinjiang, China: geochemistry and $\mathrm{Nd}-\mathrm{Sr}$ isotopic evidence, and implications for Phanerozoic crustal growth. Chem Geol 138: 135-159

HAN BF, JI JQ, Song B, Chen LH, Li ZH (2004) SHRIMP zircon $\mathrm{U}-\mathrm{Pb}$ ages of Kalatongke No. 1 and Huangshandong $\mathrm{Cu}$-Ni-bearing mafic-ultramafic complexes, North Xinjiang and geological implications. China Sci Bull 49: 2324-2328 (in Chinese)

Han CM, Xiao WJ, Zhao GC, Mao JW, Li SZ, Yan Z, MAO QG (2006) Major types, characteristics and geodynamic mechanism of Upper Paleozoic copper deposits in northern Xinjiang, northwestern China. Ore Geol Rev 28: $308-328$

Han CM, Xiao WJ, Zhao GC, Qu WJ, Du AD (2007) Re-Os dating of the Kalatongke $\mathrm{Cu}-\mathrm{Ni}$ deposit, Altai Shan, NW China, and resulting geodynamic implications. Ore Geol Rev 32: 452-468

Hu AQ, Zhang GX, Li QX, Fan SK, Zhang SF (1993) Isotope geochemistry and crustal evolution of Northern Xinjiang. In: Tu GZ (ed) New Improvement of Gold Geosciences in Northern Xinjiang. Beijing Science Publishing House, Beijing, pp 27-37 (in Chinese)
Hu AQ, JAHN BM, ZhANG GX (2000) Crustal evolution and Phanerozoic crustal growth in northern Xinjiang: $\mathrm{Nd}$ isotopic evidence. Part I. Isotopic characterization of basement rocks. Tectonophysics 328: 15-51

Hu AQ, Wei GJ, Deng WF, Chen LL (2006) SHRIMP zircon $\mathrm{U}-\mathrm{Pb}$ dating and its significance for gneisses from the southeast area to Qinghe Country in the Altai, China. Acta Petrol Sin 22: 1-10 (in Chinese with English abstract)

Jahn BM, Natalin's B, Dobretsov N (2004) Phanerozoic continental growth in Central Asia. J Asian Earth Sci 23: 599-603

Kruk NN, Rudnev SN, Vladimirov AG, Shokalsky SP, Kovach VP, Serov PA, Volkova NI (2011) Early-Middle Paleozoic granitoids in Gorny Altai, Russia: implications for continental crust history and magma sources. J Asian Earth Sci 42: 928-948

Laurent-Charvet S, Charvet J, Shu LS, Ma RS, Lu HF (2002) Paleozoic late collisional strike-slip deformations in Tianshan and Altai, eastern Xinjiang, NW China. Terra Nova 14: 249-256

Laurent-Charvet S, Charvet J, Monie P, Shu LS (2003) Late Paleozoic strike-slip shear zones in eastern central Asia (NW China): new structural and geochronological data. Tectonics 22: doi 10.1029/2001TC901047.

Li HQ, XIe CF, Chang HL, Cai H, Zhu JP, Zhou S (1998) Study on Metallogenetic Chronology of Nonferrous and Precious Metallic Ore Deposits in North Xinjiang, China. Geological Publishing House, Beijing, pp 1-264 (in Chinese)

LI XR, LIU F, YANG FQ (2012) Geological times and its significance of the two mica syenogranite in the Keyinblak $\mathrm{Cu}-\mathrm{Zn}$ deposit area in Altay, Xinjiang. Xinjiang Geo 30: 5-11 (in Chinese with English abstract)

Liu F, Yang FQ, Li YH, Guo ZL, Chai FM, Geng XX, ZHANG ZX (2010) The chronology and geochemistry of the granite from the Serbulak iron deposit in the southern margin of Altay, Xinjiang. Acta Geol Sin 84: 195-205 (in Chinese with English abstract)

Liu YL, Zhu YF, WANG DH (2003) Shear-zone related gold deposits of the southern Altai Mountains, northwestern China. In: Mao JW, Goldfarb RJ, Seltmann R, Wang DH, Xiao WJ, Hart C (eds) Tectonic Evolution and Metallogeny of the Chinese Altai and Tianshan Proceeding Volume of the International Symposium of the IGCP-473 Project in Urumqi, pp 201-208

Liu W (1993) Whole rock isochron ages of plutons, crustal movement and evolution of tectonics setting in the Altai Mts., Xinjiang Uygur Autonomous Region. Geosci Xinjiang 4: 35-50 (in Chinese)

Long LL, Wang YW, Wang JB, Wang LJ, Li QL, Wang SL, Pu KX, Zhang HQ, Liao Z (2010) Magma mixing in the Xilekuduke $\mathrm{Cu}-\mathrm{Mo}$ ore district in Xinjiang: evidence from zircon U-Pb chronology. Acta Petrol Sin 26: 449-456 (in Chinese with English abstract) 
Long XP, Sun M, Yuan C, Xiao WJ, Cai KD (2008) Early Paleozoic sedimentary record of the Chinese Altai: implications for its tectonic evolution. Sedim Geol 208: 88-100

Mao JW, Franco P, Zhang ZH, Chai FM, Wu H, Chen SP, Cheng SL, Yang JM, Zhang CQ (2008) A review of the $\mathrm{Cu}-\mathrm{Ni}$ sulphide deposits in the Chinese Tianshan and Altai orogens (Xinjiang Autonomous Region, NW China): principal characteristics and ore-forming processes. J Asian Earth Sci 32: 184-203

Mei HJ, Yang XC, Wang JD, Yu XY, Liu TG, Bai ZH (1993) The trace element geochemistry of Late Paleozoic volcanic rocks on the southern side of Ertix River and the evolutional history of tectonic setting. In: Tu GZ (ed) New Improvement of Gold Geosciences in Northern Xinjiang. Beijing Science Publishing House, Beijing, pp 199-216 (in Chinese)

Niu HC, Xu JF, Yu XY, Chen FR, Zheng ZP (1999) Discovery of Mg-rich volcanic rock series in the western Altai area, Xinjiang, and its geologic significance. China Sci Bull 44: 1685-1687

Niu HC, Sato H, Zhang H, Ito J, Yu Z, Nagao T, Terada K, ZHANG Q (2006) Juxtaposition of adakite, boninite, high- $\mathrm{TiO}_{2}$ and low- $\mathrm{TiO}_{2}$ basalts in the Devonian southern Altai, Xinjian, NW China. J Asian Earth Sci 28: 439-456

Qu GS, Zhang JL (1991) Irtys structural zone. Geosci Xinjiang 3: 115-131 (in Chinese with English abstract)

Rui ZY, Goldfarb RJ, Qiu YM, Zhou TH, Pirajno F, Yun G (2002) Paleozoic-early Mesozoic gold deposits of the Xinjiang Autonomous Region, Northwestern China. Miner Depos 37: 393-418

Safonova I, Seltmann, R, Kröner A, Gladkochub D, Schulmann K, Xiao W, Kim T, Komiya T, Sun M (2011) A new concept of continental construction in the Central Asian Orogenic Belt (compared to actualistic examples from the Western Pacific). Episodes 34: 186-194

Şengör AMC, Natal'in BA, Burtman VS (1993) Evolution of the Altaids collage and Paleozoic crustal growth in Eurasia. Nature 364: 299-307

Şengör AMC, Natal'in BA, Burtman V S (1996) Turkictype orogeny and its role in the making of the continental crust. Ann Rev Earth Planet Sci 24: 263-337

Sun M, Yuan C, Xiao WJ, Long XP, Xia XP, Zhao GC, LiN SF, Wu FY, KRÖNER A (2008) Zircon U-Pb and Hf isotopic study of gneissic rocks from the Chinese Altai: progressive accretionary history in the early to middle Palaeozoic. Chem Geol 247: 352-383

Thorkelson DJ, BReITSPReCHER K (2005) Partial melting of slab window margins: genesis of adakitic and nonadakitic magmas. Lithos 79: 25-41

Travin AV, Boven A, Plotnikov AV, Vladimirov VG, Theunissen V, Ladimirov AG, Melnikov AI, Titov AV (2001) ${ }^{40} \mathrm{Ar} /{ }^{39} \mathrm{Ar}$ dating of ductile deformations in the Irtysh shear zone eastern Kazakhstan. Geochem Int 39: 1237-1241
Wan B, Zhang LC, Xiang P (2010) The Ashele VMS-type $\mathrm{Cu}-\mathrm{Zn}$ deposit in Xinjiang, NW China formed in a rifted arc setting. Resour Geol 60:150-164

Wan B, Xiao WJ, Han CM, Brian FW, Zhang LC, Qu WJ, Du AD (2014) Re-Os molybdenite age of the $\mathrm{Cu}-\mathrm{Mo}$ skarn ore deposit at Suoerkuduke in East Junggar, NW China and its geological significance. Ore Geol Rev 56: 541-548

WANG DH (2003) Geology, geochemistry and geodynamics of the Ashele VHMS Cu-Zn deposit, northwestern Xinjiang. In: Mao JW, Goldfarb RJ, Seltmann R, Wang DH, Xiao WJ, Hart C (eds) Tectonic Evolution and Metallogeny of the Chinese Altai and Tianshan. Proceeding Volume of the International Symposium of the IGCP-473 Project in Urumqi, pp 153-168

Wang DH, Chen YC, Xu ZG, Li TD, Fu XJ (2002) Minerogenetic series of mineral deposits and regularity of mineralization in the Altaid metallogenic province, Xinjiang, China. Atomic Energy Press, Beijing, pp 1-498 (in Chinese)

Wang JB, Qin KZ, Wu ZL, Hu JH, Deng JN (1998) Volcanic-Exhalative-Sedimentary Lead-Zinc Deposits at the Southern Margin of the Altai, Xinjiang. Geological Publishing House, Beijing, pp 1-210 (in Chinese)

Wang JB, Wang YW, Wang S L, Ding RF (2003) The Koktal $\mathrm{Pb}-\mathrm{Zn}$ massive sulfide deposit. In: MaO JW, Goldfarb RJ, Seltmann R, Wang DH, Xiao WJ, Hart $\mathrm{C}$ (eds) Tectonic Evolution and Metallogeny of the Chinese Altai and Tianshan. Proceeding Volume of the International Symposium of the IGCP-473 Project in Urumqi, pp 169-180

Wang RM, ZhaO CL, Ma WP, Zhou YX, Zhang YB (1991) No. 1 Ore Deposit at Kalatongke of Xinjiang. Geological Publishing House, Beijing, pp 1-319 (in Chinese)

Wang T, Hong DW, Tong Y, Han BF, Shi YR (2005) Zircon U-Pb SHRIMP age and origin of post-orogenic Lamazhou granitic pluton form Altai orogen: its implications for vertical continental growth. Acta Petrol Sin 21: 640-650 (in Chinese with English abstract)

WANG YW, WANG JB, WANG SL, Ding RF, WANG LJ (2003) Geology of the Mengku iron deposit, Xinjiang, China - a metamorphosed VMS? In: MAO JW, GoldFARB RJ, Seltmann R, Wang DH, Xiao WJ, Hart C (eds) Tectonic Evolution and Metallogeny of the Chinese Altai and Tianshan. Proceeding Volume of the International Symposium of the IGCP-473 Project in Urumqi, pp 181-200

Wang YW, Wang JB, Wang SL, Long LL, Wang LJ, Pu KX, WAng SD, TANG PZ (2010) Geological characteristics and genesis of the Xilekuduke $\mathrm{Cu}-\mathrm{Mo}$ deposit, Xinjiang. Xinjiang Geol 28: 370-376 (in Chinese with English abstract)

WANG Z (1991) Geological feature of Duolanasayi gold deposit in Xinjiang. Xinjiang Geol 9: 72-79 (in Chinese with English abstract) 
Windley BF, Kröner A, Gu JH, Qu GS, Li YY, Zhang C (2002) Neoproterozoic to Paleozoic geology of the Altai orogen, NW China: new zircon age data and tectonic evolution. J Geol 110: 719-739

Windley BF, Alexeiev D, Xiao W J, Kröner A, Badarch $\mathrm{G}$ (2007) Tectonic models for accretion of the Central Asian Orogenic Belt. J Geol Soc, London 164: 31-47

Wu GG, Dong LH, Xue CJ, Feng J, Tan HD, Zhang ZC, Wen CS, Zhou G, Gong QJ, Gao JG, Du YS, He MY, LiU JL, Tu QJ (2008) The Main Porphyry Copper Ore Belts in Northern Xinjiang China. Geological Publishing House, Beijing, China, pp 1-345 (in Chinese)

Xiao WJ, Windley BF, Badarch G, Sun S, Li JL, Qin KZ, WANG ZH (2004) Palaeozoic accretionary and convergent tectonics of the southern Altaids: implications for the lateral growth of Central Asia. J Geol Soc, London 161: 339-342

Xiao WJ, Han CM, Yuan C, Sun M, Lin SF, Chen HL, Li ZL, Li JL, Sun S (2008) Middle Cambrian to Permian subduction-related accretionary orogenesis of Northern Xinjiang, NW China: implications for the tectonic evolution of central Asia. J Asian Earth Sci 32: 102-117

Xu LG, Mao JW, Yang FQ, Daniel H, Zheng JM (2010) Geology, geochemistry and age constraints on the Mengku skarn iron deposit in Xinjiang Altai, NW China. J Asian Earth Sci 39: 423-440

Yan SH, Zhang ZC, Wang DH, Chen BL, He LX, Zhou G (2003) Kalatongke metallogenic copper-nickel sulfide deposit. In: Mao JW, Goldfarb RJ, Seltmann R, Wang DH, Xiao WJ, Hart C (eds) Tectonic Evolution and Metallogeny of the Chinese Altai and Tianshan. Proceeding Volume of the International Symposium of the IGCP-473 Project in Urumqi, pp 17-30

Yan SH, Chen W, Wang YT, Zhang ZC, Chen BL (2004) ${ }^{40} \mathrm{Ar} /{ }^{39} \mathrm{Ar}$ dating and its significance of the Ertix gold metallogenic belt in the Altai orogen, Xinjiang. Acta Geol Sinica 78: 500-505 (in Chinese)

Yang FQ, Yan SH, Qu W, Zhou G, Liu F, Geng XX, Liu GR, WANG X (2010) The fluid inclusions and C, H and $\mathrm{O}$ isotopic geochemistry of the I mineralized zone at the Halasu copper deposit, Xinjiang. Earth Sci Frontier 17: 359-374 (in Chinese with English abstract)

Yang FQ, Mao JW, Pirajno F, Yan SH, Liu GR, Zhou G, ZhANG ZX, Liu F, Geng XX, Guo CL (2012) A review of the geological characteristics and geodynamic setting of Late Paleozoic porphyry copper deposits in the Junggar region, Xinjiang Uygur Autonomous Region, northwest China. J Asian Earth Sci 49: 80-98

Yang FQ, Mao JW, Liu F, Chai FM, Geng XX, Zhang ZX, GuO XJ, LIU GR (2013) A review of the geological characteristics and mineralization history of iron deposits in the Altay orogenic belt of the Xinjiang, northwest China. Ore Geol Rev 54:1-16

Yang FQ, Chai FM, Zhang ZX, Geng XX (2014) Zircon $\mathrm{U}-\mathrm{Pb}$ geochronology, geochemistry, and $\mathrm{Sr}-\mathrm{Nd}-\mathrm{Hf}$ isotopes of granitoids in the Yulekenhalasu copper ore district, northern Junggar, China: petrogenesis and tectonic implications. Lithos 190-191: 85-103

Yang WP, Zhang ZC, Zhou G, Yan SH, He LX, Chen BL (2005) Discovery of the Xileketehalasu porphyry copper deposit on the southern margin of the Altai copper metallogenic belt. Geol China 32: 107-114 (in Chinese with English abstract)

Yakubchuk A, Seltmann R, Shatov V (2003) Tectonics and metallogeny of the western part of the Altaid orogenic collage. In: MaO JW, GoldFarb RJ, SEltmann R, Wang DH, Xiao WJ, Hart C (eds) Tectonic Evolution and Metallogeny of the Chinese Altai and Tianshan. Proceeding Volume of the International Symposium of the IGCP-473 Project in Urumqi, pp 7-16

Yu XY, Mei HJ, Yang XC, WANG JD (1993) Ertix volcanic rocks and tectonic evolution. In: Tu GZ (ed) NewImprovement of Gold Geosciences in Northern Xinjiang. Beijing Science Publishing House, Beijing, pp 185-198 (in Chinese)

Zhang ZC, Mao JW, Zhou G, Chai FM, Yan SH, Chen BL (2005) Geochemistry of the Kalatongke layered intrusion, Xinjiang NW China: implications for the genesis of a magmatic $\mathrm{Cu}-\mathrm{Ni}$ sulfide deposit. In: MAO JW, FRANK PB (eds) Mineral Deposit Research: Meeting the Global Challenge. Proceedings of the Eighth Biennial SGA Meeting, Beijing, China, pp 489-502

Zhang ZC, Yan SH, Chen BL, Zhou G, He YK, Chai FM, HE LX, WAN YS (2006) SHRIMP zircon U-Pb dating for subduction-related granitic rocks in the northern part of east Junggar, Xinjiang. Chin Sci Bull 51: 952-962

Zhang ZX, Yang FQ, Li C, Liu F, Geng XX, Liu GR, Chai FM, OUYANG LJ (2012) Rock-forming and ore-forming ages of Qiaoxiahala $\mathrm{Fe}-\mathrm{Cu}-\mathrm{Au}$ deposit on northern margin of Junggar Basin, Xinjiang. Miner Depos 31: 347-358 (in Chinese with English abstract)

Zhao ZF, Xun CJ, Zhang LW, Wen CS, Zhou G, Liu GR (2009) U-Pb dating of zircons from acid intrusions in Yulekenhalasu copper deposit of Qinghe, Xinjiang, and its geological significance. Miner Depos 28: 425-433 (in Chinese with English abstract)

Zhao ZH, Wang ZG, Zou TR, Masuda A (1993) The REE, isotopic composition of $\mathrm{O}, \mathrm{Pb}, \mathrm{Sr}$ and $\mathrm{Nd}$ and diagenetic model of granitoids in Altai region. In: Tu GZ (ed) New Improvement of Gold Geosciences in Northern Xinjiang. Beijing Science Publishing House, Beijing, pp 1-266 (in Chinese)

Zheng CQ, Kato T, Enami M, Xu XC (2007) CHIME monazite ages of metasediments from the Altai orogen in northwestern China: Devonian and Permian ages of metamorphism and their significance. The Island Arc 16: 598-604

Zhou TF, Yuan F, Yue SC, Yuan XY (2000) Magmatism and mineralization of Nuoerte in Xinjiang. Geological Publishing House, Beijing, pp 1-125 (in Chinese) 